\title{
Lähtökielen sanansisäisten soinnittomien klusiilien edustus kantasuomen balttilaislainoissa: Osa II. Edustus kohdekielen pitkän tavuaineksen jäljessä
}

In this article I intend to prove that the word-internal Baltic tenuis consonants $k, t$ and $p$ after a long syllable appear as the single stops $k, t$ and $p$ in old Baltic loanwords in Proto-Finnic in all regular instances, to confirm that all Finnic geminate stops after a long syllable have arisen after the end of the contacts between Baltic and Proto-Finnic.

I will critically assess the Baltic loan etymologies which contain geminate stops $k k, t t$ and $p p$ after a long syllable, at which point most of such etymologies will be rejected, and either the long syllable or the geminate stop in the Baltic loanwords kaikki, laukko and peikko in Finnish, malk and kurt in Estonian, will be shown to be secondary. Vowel contraction, like in kaikki, will be claimed as a frequent source of Finnic -ai-. In the possible Baltic loanwords haukkua, paukkua, ronkkua, harakka and peippo, the geminate stop will be explained as onomatopoeic. The two historically geminated Baltic borrowings, South Estonian kaugas and ärk', originate from more recent local contacts with Old Latgalian.

I will give more credible etymological explanations for 29 Finnic words, once claimed to be of Baltic origin. 18 of these explanations are already known, but I will specify the etymologies given to Finnish aitta, seitti, vaikku and Estonian kärpima, and support the origins of Finnish kartta, riitta and South Estonian kirges with new arguments. I will suggest new etymologies for 11 words: Finnish haitta, karppa, kurpponen, liettää, porkkana, Karelian nautti, Estonian karp, paat, Livonian kerk, South Estonian käo|kirg' and virp'.

I will also present several cases, where words of different origin with similarities in both form and meaning have an influence on each other's phonological and/or semantic development.

Tämän artikkelin ensimmäisessä osassa (Junttila 2017) tarkastelin lähtökielen sanansisäisten klusiilien edustusta kantasuomen balttilaisissa lainoissa ensi tavun lyhyen tavuaineksen eli lyhyen vokaalin jäljessä. Osoitin, että lähtökielen sanansisäiset tenuikset $k, t, p$ edustuvat tällöin kohdekielen geminaattaklusiileina $k k, t t, p p$ kaksitavuisissa, mutta yksittäisklusiileina $k, t, p$ kolmitavuisissa nominivartaloissa. ${ }^{1}$ Tällaisen substituutiosäännön löytyminen viittaa kantasuomen tavurakenteen pysyvyyteen balttilaiskontaktien kaudella. Vain harvalukuisissa verbivartaloissa klusiiliedustus horjuu. Lähtökielen sanansisäiset mediaklusiilit $b, d, g$ edustuvat aina

1. Ensimmäisessä osassa jäi käsittelemättä sm. jutta, jolle ensinnä esitetyssä lähtömuodossa on konsonanttiyhtymä -ngt- (Ojansuu 1921: $8 \leftarrow$ lt. jungtas 'yhdistetty, iestetty'), mutta jolle sittemmin esitettiin myös hypoteettinen -t-llinen lähtömuoto *jutas (Posti 1977: 263-264). Tältä lähtömuodolta puuttuvat tarkat baltoslaavilaiset vastineet, mutta periaatteessa sekin on mahdollinen ja tukee esittämiäni päätelmiä. 
kohdekielen yksittäisklusiileina $k, t, p$, sillä soinnillisten klusiilien ominaispituus on lyhempi kuin soinnittomien.

Tässä jälkimmäisessä osassa pyrin osoittamaan, että kantasuomen balttilaislainoissa ei esiinny alkuperäisiä, lainautumishetkeen palautuvia geminaattaklusiileita pitkän tavuaineksen jälkeen: sekä lähtökielen mediat että tenuikset edustuvat siis yksittäisklusiileina $k, t, p$. Muita geminaattakonsonantteja kuin klusiileita ei balttilaislainoihin ole esitetty yhdessäkään kannatusta saaneessa etymologiassa (vrt. Junttila 2015b: 88-117), joten tämä osoittaisi, että kantasuomen sanavartaloitten konsonanteilla oli vielä balttilaiskontaktien aikaan eli keskikantasuomen kauden loppuun asti pituusoppositio ainoastaan lyhyen vokaalin jäljessä. Tällaisen rajoituksen tiedetään vanhastaan olleen voimassa uralilaisesta kantakielestä vähintään varhaiskantasuomeen asti (vrt. Lehtinen 2007: 56, 63).

Uralilaisesta kantakielestä periytyvästä sanastosta (vrt. Itkonen 1961: 66-69) poiketen balttilaislainoissa on jo keskikantasuomeen rekonstruoitavia (C)VVC- ja (C)VCC-tyypin ylipitkiä ((C)VC- ja (C)VV- eli pitkiä tavuja pitempiä) tavuja, sillä ainakin lainaetymologiat sanoille rieska $<(\mathrm{kksm}$.) *reeska, siula $<*$ tinkla, raaja $<$ *rankja, taaja $<*$ tankja, ahdas $<*$ anštas ja varsta $<*$ varsta vaikuttavat uskottavilta. Pitkän tavuaineksen jälkeisiä geminaattojakin esiintyi ehkä morfeeminrajoilla niin taivutuksessa, esim. kansi : part. kant|ta, kuin sananjohdossa, esim. kattaa < *kant|ta-, tuttava $<*$ tunt $\mid t a-$, elleivät nämä ole konsonanttivartalon myöhempää analogista leviämistä. Kantasuomen - $t A$-johtimella on varustettu myös lukuisia vanhoja lainaverbejä, joista balttilaisperäisinä on pidetty sanoja pettää Koivulehto (2009: $96<$ *pent|tä- $\leftarrow$ ba. *spend-) ja kiittää (Liukkonen 1999: 75-76<*keit|tä- $\leftarrow$ ba. *geid-).

Lähden kuitenkin oletuksesta, että vartalonsisäiset pitkän tavuaineksen jälkeiset geminaatat tulivat kieleen vasta balttilaiskontaktien päätyttyä. Täten minun on pyrittävä kumoamaan kaikki balttilaisetymologiat, joihin niitä on rekonstruoitu. Morfeeminrajaisen geminaatan sisältävät verbit pettää ja kiittää jäävät tämän esityksen ulkopuolelle. Pidän lisäksi tarpeettomana käsitellä useimpia sellaisia etymologioita, joita ei ole kannattanut kukaan muu kuin niitten esittäjä. Kymmenien kannatuksettomien etymologioitten joukosta otan esille vain sanat, joille on balttilaisetymologiaa esitetty niin hiljattain, ettei niitten alkuperää sen jälkeen ole ehditty mainita sanakirjoissa tai muussa tutkimuskirjallisuudessa. ${ }^{2}$

2. Artikkelini ensimmäisessä osassa käsittelin vain etymologioita, jotka väitöskirjassani (Junttila 2015b) olin luokitellut yleisesti hyväksytyiksi, kiistanalaisiksi tai vielä arvioimattomiksi. Tällä välin olen kuitenkin väljentänyt kriteereitä käsittelyyn otettaville etymologioille, sillä kaikkia aiemmin kannatettuja mutta kannatuksensa menettäneitä etymologioita ei ole uskottavasti kumottu. Näillä kriteereillä olisi lyhyen vokaalin jälkeisistä tapauksista mainittava, että balttilaislainaselitykset sanoille sm. rata, vi. täkk 'ori' ja li. plaka 'lude' on uskottavasti kumottu (Nieminen 1940: 381; Junttila 2014: 129; Junttila 2015b: 240) ja balttilaislainaselitystä todennäköisempi muu etymologia on esitetty sanoille sm. katu (GSI 63, $93 \leftarrow$ mru.), sato (Aikio 2014: 14-17 = md. ma. mns. ha.), tosi (Aikio 2015a: 3-5 = mns. ha.) ja vs. pakal' (EEW $\leftarrow$ ven.). Tutkimisen arvoisia olisivat kuitenkin vielä balttilaisetymologiat sm. haven $\leftarrow$ lt. šapas 'olki; akana' (Hahmo 1990: 212), sm. lattea $\leftarrow$ lt. platus, lv. plats 'leveä' (BFB 208-9) ja sm. rapea $\leftarrow$ lt. trapus 'hauras, helposti mureneva, rapea' (Junttila 2015b: 220). Sm. suka on tässä käsiteltyjä balttilaislainoja vanhempi laina (Kallio 2009: 32-33), mikä voi liittyä sen yksittäisklusiiliedustukseen. 
Kannatettujenkin balttilaisetymologioitten joukossa on peräti 42 sanaa, joissa pitkän tavuaineksen jälkeen esiintyy vartalonsisäinen geminaattaklusiili joko yksinomaisena tai vähintään joissakin varianteissa. Tavutyypin suhteen ne jakautuvat tasan: 21 sanassa geminaattaklusiilia edeltää resonantti ja toisissa 21 sanassa pitkä vokaali tai diftongi. Käsittelen niitten etymologiat tässä järjestyksessä. Kokoan sekä aiemmin esitettyjä että uusia perusteita näitten sanojen balttilaisperäisyyttä vastaan. Eräille sanoille esitän uudet etymologiat.

\section{Edustus resonantin jäljessä: yksittäisklusiilitapaukset}

Balttilaislainaetymologioissa ylivoimaisesti yleisin konsonanttiyhtymätyyppi on resonantti $\mathrm{R}\{\mathrm{mnlr}\}+$ obstruentti $\mathrm{K}\{\mathrm{ptksh}\}$. Ei olekaan yllättävää, että ensimmäinen ja tähän mennessä ainoa esitetty balttilaislainojen tavurakennetta rajoittava sääntö koskee juuri niitä. Nikkilän (1982) germaanisia lainoja käsittelevässä artikkelissansa esittämän äännerakennekriteerin mukaan alkuperäisen likvidan jälkeisen geminaatan sisältäviä sanoja ei voi pitää vanhoina balttilaislainoina. Vasta alempana tässä artikkelissa osoitan saman säännön pätevän kaikkiin pitkän tavuaineksen jälkeisiin asemiin.

Keskikantasuomen ensi tavun resonanttia seuraa yksittäisklusiili (nykykielten asuihin ovat sittemmin vaikuttaneet astevaihtelu ja $t i>c i>s i$-muutos) 99 sanassa, jolle on esitetty ja kannatettu balttilaista lainaetymologiaa. Varmasti balttilaisperäisiä näistä ovat sm. angervo, ankerias, arta, elki elje, hammas, hanko, helle, härkä, irta-, kampi, kannel, karve, kelta $(\Rightarrow$ keltainen), kinnas, kirpeä, kirsi, korsi, lenko 'kaari', lunki lunka, morsian, mäntä, märkä, orsi, rampa, rentiä 'kahlata, rämpiä', räntä, salko (oik. Ł esiba.), sampi, silta, särky, talkoot, temmata, varras, varsi, vinka 'häkä', virka 'ansarivi', virpi 'oksa', virsi, virta, ve. bärbitada 1i. vērbikšy $y^{3}$ 'kehrätä', vi. kild 'lastu' (? = sm. kelle), vingerjas 'mutakala, iso kivennuoliainen' ja vs. vang 'joenmutka' sekä ainakin jotkin sanoista sm. hinta, hirsi, karsina, karta, kerta, kinner $\sim$ kinttu, kärvetä, lampi, lanko, lumme, lännys, parta, perkele (? vi. põrgu 'helvetti'), portimo, päntä 'pesue', ranne, ranta, sammas, suunta, särpiä, varpa, vi. kurb 'surullinen', talb 'kiila', värb(lane) 'varpunen', li. mändryks 'mäntä, mela' ja vs. läng

3. Käyttämäni liivin ortografian neljä kirjaliivistä eroavaa piirrettä mainitsen väitöskirjassani (Junttila 2015b: 40). Huomattavin on $y$ ensitavun suppean lavean taka- tai keskivokaalin sekä jälkitavujen redusoidun vokaalin merkkinä, kuten runoilija Ķempi Kārlilla, mutta toisin kuin kirjakielessä, jossa sen sijalla on $\tilde{o}$. Kirjakieltä lukiessa vaikeuksia tuottaa $\tilde{o}$-kirjaimen erottaminen yhtä lailla yleisestä pitkän vokaalin merkistä $\bar{o}$. 
'hunajankerääjän työkalu'. Lisäksi kumottuja tai paremmalla selityksellä korvattuja lainaetymologioita on esitetty 30:1le äännerakenteeltaan vastaavanlaiselle sanalle. ${ }^{4}$

Tuoreita, toistaiseksi arvioimattomia balttilaisetymologioita on esitetty sanoille sm. kylki $\leftarrow$ ba. *kulkV- (Junttila 2015b: 212) ja vi. hargnema 'haarautua' $\leftarrow$ lt. žergti (Junttila \& al. 2015). Uutta alkuperänselitystä ehdotan aiemmin etymologioimattomalle sanalle sm. ka. kirki, vi. kirg 'kiima, lemmenkiihko; himo, halu', vs. kirg' 'kipinä; liekki', li. ķireg 'kipinä'. Sanan vanhimmaksi merkitykseksi osoittautuu jo Hakulisen (1933) tutkielmassa konkreettinen 'kipinä', jolle on ilmiselvä lainalähde balttilaisella taholla: lv. dzirksts, dzirkstele, (murt.) dzirkste 'kipinä' (< kba. *gir-k-). Latvian sana kuuluu indoeurooppalaisessa kielikunnassa laajaan palamiseen ja lämpöön liittyvään sanapesyeeseen: 1t. garas 'höyry; himo, kiihkeys, into, ahkeruus' mksl. горвти 'palaa', пожарь 'palo', lat. formus 'lämmin', ru. varm id. (LEW s.v. garas).

Kaksi uutta etymologiaa on hylättävä. Däbritzin (2015: 15-16) oletuksen sm. renta 'suhde' $\leftarrow$ lt. rinda 'jono, rivi' vokaaliedustukselta ksm. en- $\leftarrow$ ba. in puuttuu paralleeli. Vaban (2015) etymologiassa vs. sirdus : - $\tilde{o}$ 'kimppu pellavia t. hamppuja köyden valmistamiseksi' $\leftarrow$ lt. skiedra 'lastu, päre' ongelmana ovat sekä muoto että merkitys (odottaisi muotoa **kõdyr ***kõtr).

Kaikkiaan 20-33 sanan balttilaisessa lähtömuodossa ${ }^{5}$ on soinniton klusiili: sm.

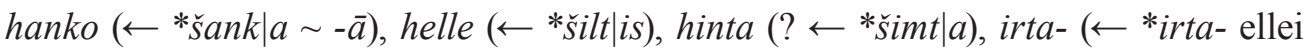
soinnillinen *irda-), kampi $(\leftarrow * k a m p \mid i j a)$, kannel $(\leftarrow * k a n t l \mid \bar{e})$, karve $(\leftarrow * k e r p \mid \bar{e})$, kelta $\left(\leftarrow *^{*}\right.$ gelt $\left.\mid \bar{a}\right)$, kinner $\left(? \leftarrow{ }^{*}\right.$ kink-), kirki $\left(\leftarrow *^{*}\right.$ girk-), kirpeä $(\leftarrow *$ kirp- ellei soin-

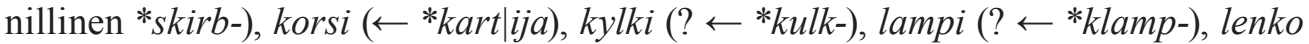
$(\leftarrow * l e n k \mid a \sim-\bar{a})$, lunki lunka $(\leftarrow *$ lunk $\mid a)$, morsian $(\leftarrow *$ mart $\mid i j a \bar{a})$, mäntä $\left(\leftarrow{ }^{*}\right.$ ment $\left.\mid \bar{e}\right)$, märkä $(\leftarrow$ merk $\mid a \sim-\bar{a})$, perkele $\left(? \leftarrow{ }^{*}\right.$ perk $\left.|\bar{u} n| a s\right)$, portimo $\left(? \leftarrow{ }^{*}\right.$ spart $\left.|e i v| \bar{a}\right)$, päntä $\left(? \leftarrow{ }^{*}\right.$ pent $\left.\mid \bar{e}\right)$, ranta $(? \leftarrow * k$ kanta $)$, räntä $(\leftarrow *$ drengta $)$, silta $(\leftarrow *$ tilt $\mid a)$, suunta $(?$ $\leftarrow{ }^{*}$ sunt $\left.\mid \bar{a}\right)$, talkoot $(\leftarrow *$ talk $\mid \bar{a})$, temmata $(\leftarrow$ temp $\mid j a-)$, varpa $(? \leftarrow *$ varp-), virta $(\leftarrow$ *virt $\mid a \sim-\bar{a})$, ve. bärbitada 1i. vērbikšy $(\leftarrow *$ verp $\mid j a-)$, vi. kild $\left(\leftarrow *^{*}\right.$ skilt|ija) ja li. mändryks $\left(? \leftarrow{ }^{*}\right.$ ment $\left.|u r| \bar{e}\right)$.

4. Kaikkiaan 20 sanan väitetty balttilaisperäisyys on uskottavasti kumottu tutkimuskirjallisuudessa (sm. ilta Rédei 2000: 227, kalpa Junttila 2015b: 214, karsi Junttila 2015b: 200, kartano BFB 153, karvas 'vene' Junttila 2016a: 139, kuontalo Setälä 1893: 203-204 ja Mikkola 1894: 130, lintu Rédei 2000: 228, länsi Nikkilä 2001: 398, panki Setälä 1915: 78-80, ranget Junttila 2012: 281, runko Koivulehto 1997: 13, särki Junttila 2012: 271, tarpa Junttila 2012: 270, turku BFB 12, valkea Linde 2007: 179, vannas Junttila 2016a: 139, va. vonka 'aalto' Linde 2007: 179, vi. kõngema 'oikaista koipensa' Junttila 2016b: 469, urg 'pesäkolo, pesäluola' Junttila 2011: 106 ja vend 'veli' Junttila 2015b: 182) ja lisäksi 10:n sijalle on esitetty parempi etymologia (sm. haltia Karsten 1943-44: $103 \leftarrow$ germ. t. Mägiste 1956: $7 \Leftarrow$ hallita, kaltainen Kettunen 1934: $172 \sim$ kallas, karpio BFB $183 \leftarrow$ sl., karsia Koivulehto 1971c $\leftarrow$ germ., kurko Aikio 2009: 189-191, kärpänen Lindström 1852: 52 = md. ma., kärväs Koivulehto 1971b: 585-592 germ., parsi Aikio 2015b: 63 = mns. ha., ranka Saxén 1895-98: $206 \leftarrow$ sk. t. Toivonen 1919: $106 \leftarrow$ germ., vinka 'koukku' Aikio 2009: 176-178 $\leftarrow$ saa.).

5. Kaikki lähtömuodot ovat kantabaltin sanojen tai sanankantojen summittaisia rekonstruktioita. Useimpien vastineet nykyisissä baltoslaavilaisissa kielissä merkityksineen on mainittu väitöskirjassani (Junttila 2015b). Tässä en käsittele näitä klusiiliedustuksen kannalta enimmäkseen ongelmattomia etymologioita enempää. 
Yksittäisklusiiliedustuksen runsaus tukee Nikkilän kriteeriä. Sitä ei kuitenkaan ole sovellettu balttilaislainaetymologioita arvioitaessa. Kuudessa balttilaislainana pidetyssä itämerensuomen sanassa ja yhdessä vielä arvioimattomassa etymologiassa (vahvan asteen) yksittäisklusiili vaihtelee (vahvan asteen) geminaatan kanssa kielittäin tai murteittain, ja peräti kolmessatoista balttilaisperäisenä pidetyssä sanassa sekä kahdessa vielä arvioimattomassa etymologiassa näyttää olevan yksinomainen geminaattaedustus (vahvassa asteessa; kaikki alla käsitellyt muodot on ryhmitelty vahvan asteen mukaan). Eräissä näistä sanoista geminaattaa vastaa balttilaisella taholla suorastaan soinnillinen klusiili. Alla käsittelen ensin vaihtelutapaukset ja niitten jälkeen sanat, joissa geminaattaklusiili näyttää vastaavan balttilaista klusiilia.

\section{Edustus resonantin jäljessä: vaihtelutapaukset}

Vaikka vain kuudessa kannatetussa ja yhdessä arvioimattomassa balttilaisetymologiassa on kvantiteetiltaan horjuva klusiiliedustus, mahtuu ryhmään morfologian tasolta katsottuna monenlaisia vaihteluita, joitten taustalla vaikuttavat useat eriaikaiset muutokset kielen eri tasoilla. Käsittelen ensin luonteeltaan onomatopoieettiset sanat sm. harakka, li. keŗk 'kotisirkka' ja sm. ronkkua, sitten adjektiivit sm. synkeä ja vi. kurt 'kuuro' ja lopuksi etymologisesti ongelmallisimmat sanat malka ja kurpponen.

ly. ve. harag, va. araga, li. aragys $\sim$ sm. ink. ka. harakka, vi. harakas, vs. harak $\leftarrow$ 1t. šarka id. (Donner 1884: 266)

Eniten muusta ryhmästä poikkeaa harakka, jossa resonantin ja klusiilin väliin näyttää ilmestyneen vokaali vailla vastinetta lähtökielessä. Syynä lienee fonologinen 1. onomatopoieettinen 1. ikoninen nativisaatio: kba. * ${ }^{s} a r k \bar{a}$ on jo lainautuessaan saanut linnun ääntä jäljittelevän kolmitavuisen asun kksm. *̌saraka, jonka klusiili on kantasuomen kauden jälkeen kielittäin pidennyt säästyäksensä sanan ikonista asua uhanneelta toisen ja kolmannen tavun välisten klusiilien säännönmukaiselta kadolta tai heikkenemiseltä $-k->-j-\sim-v$ - eli ns. suffiksaaliselta astevaihtelulta (Junttila 2015b: 143).

Samankaltainen pääte-edustus on toisessakin linnunnimessä: sm. kajakka, vi. kajakas, vs. kajak sm. kajava, kajaa, kajaja ym., ly. ve. kajag, va. kajaga, li. kajag. Lyydissä, vepsässä, vatjassa ja liivissä, joissa "suffiksaalinen astevaihtelu" ei uhannut kantasuomen yksittäis- $k$-n klusiiliutta, edustuu alkuperäinen lyhyt klusiili, kun taas suomen murteissa, virossa ja etelävirossa sana on mukautunut yleiseen $k k A$ nominijohdostyyppiin: vrt. sm. mustikka, ink. ka. mussikka, ve. muśtik, va. musikaz, musikka, vi. mustikas, li. muškys, vs. mustik ( $\Leftarrow$ musta, vrt. SSA). Virossa tähän tyyppiin ovat siirtyneet myös eräät puunnimet, kuten balttilaisperäinen *kataka $>$ vi. kadakas sm. kataja, katava, ink. kattāja, ka. kataja, ly. kadai, ve. kadag, kadag, va. kataga, li. kadag, vs. katai, mutta suomessa ja etelävirossa mukautuminen on 
tapahtunut vain linnunnimissä, joissa $-k$-n säilyttämiselle on ollut selvä äänteellinen motivaatio.

vs. kirges 'torakka' käokirg' 'leppäkerttu' 1i. keŗk 'kotisirkka'

$\leftarrow$ lv. circenis 'sirkka' (Penttilä 1938: 495)

Paitsi lintujen, myös sirkkojen, heinäsirkkojen ja hepokattien nimityksille on tyypillistä ääntä jäljittelevä alkuperä sekä äänen ja nimityksen välisen yhteyden säilyttämään pyrkivä ikoninen nativisaatio. Joko onomatopoieettista alkuperää tai sekundaaristi onomatopoieettisia ovat sekä sm. sirkka ja kilkki itämerensuomalaisine vastineineen että liettuasta tavattavat sirkan ja muitten sirittävien hyönteisten nimitykset čirkšlys, kirklys, kurklys, parplys, svirplys ja turklys. Sekä balttilaisissa että itämerensuomalaisissa kielissä niitten käyttö on laajennut koskemaan myös kilkkejä, sirkkoja ulkoisesti muistuttavia äyriäisiä. Molemmat merkitykset on tavattu myös liivin sanalta keŗk, Sal. ķirik< mksm. *kirkki (ksm. $i>$ li. e /_r, Kettunen LW: xxiv). Se ei voi olla peräisin lätin sanasta circenis 'sirkka', sillä siinä ei edustu ristiretkiajan edelle ajoitettu latvian äänteenmuutos $k>c$. Ei myöskään ole mitään syytä olettaa näin suppealevikkisen sanan lainautuneen balttilaiselta taholta aiemmin, sillä se selittyy itämerensuomessa laajalti levinneitten sanojen sirkka ja kilkki kontaminaationa. Kontaminaatiot ovat tyypillisiä onomatopoieettiselle sanastolle.

Liivin sanan balttilaisesta etymologiasta on haettu tukea myös eteläviron sanojen kirges 'torakka' ja käokirg' 'leppäkerttu' alkuperän selittämiselle (Koponen 1998: 102). Ei ole kuitenkaan mitään näyttöä siitä, että sirkankaltaisen sirittävän hyönteisen nimi olisi siirtynyt torakalle, saati leppäkertulle. Syöpäläisinä esiintyvät torakat ovat alkuaan trooppisia lajeja ja levinneet pohjoiseen lähinnä sotajoukkojen mukana (Huldén 2008: 31-36). Niinpä torakan nimitykset ovat koko Euroopassa nuoria ja usein alkuperältään pejoratiivisesti käytettyjä etnonyymejä. Myös vs. kirges $\sim$ kirges' $\sim$ kirgets' $\sim$ kirgats' palautuu venäjän Pihkovan murteen sanaan киргиз 'kirgiisi, kazakki; torakka' (Blokland 2005: 115). Kirges on $-s E-<* k s E$-vartaloinen nomini, joita ei balttilaislainoissa ole.

Myös sanojen kirges ja käo|kirg' (: -kire) keskinäinen yhteys on sekundaari. Käkeä (vs. kägo : käo) ja leppäkerttua yhdistää ainakin se, että molemmat on kansanuskomuksissa liitetty kuoleman enteisiin. ${ }^{6}$ Leppäpirkon itämerensuomalaisia nimeämismotivaatioita ryhmitellyt Kustaa Vilkuna (Juvas \& Vilkuna 1935: 204-205) ${ }^{7}$ liittää lastenloruissa yleiseen leppäpirkon lennosta ennustamiseen sen karjalaisen nimen arboilindu.

Sanan käo|kirg' alkuperää valaisevat synonyymit käo|kiräs (: -kiräse), käo|kiri (: -kiŕä) ja käo|lehm (: -lehmä). Kiräs merkitsee kaksi- tai useampiväristä lehmää ja kiri kuviota (VES). Vilkuna (mts. 197-198) mainitsee ne motivaation 'kirjava'

6. 'Käkeen' saattaa jotenkin kuulua myös sm. kännä, kännö 'leppäkerttu'.

7. Viitteistä Huldénin ja Juvaksen \& Vilkunan teoksiin kiitän tämän artikkelin nimetöntä vertaisarvioijaa. 
alla. Leppäpirkon huomiota herättävä väritys onkin mitä luontevin nimenantoperuste. Lehmään taas liittyvät myös suomen murteitten jumalanlehmä, ukoinlehmä ja lehmänpaimen sekä eteläviron taivaäti lehm (mts. 200-203). Täplikkäitä, parvina liikkuvia ja "laiduntavia" leppäkerttuja on voitu kutsua 'käen karjaksi'. Paljon vaikeammalta tuntuisi löytää syy nimittää niitä 'käen sirkoiksi' tai 'käen torakoiksi'. Muodon käokirg' taustalla on varmaankin käokiri, jolloin uuden muotovariantin motivaationa on ollut leppäpirkon kiiltävän punaisen kuoren herättämä sekundaari assosiaatio sanaan kirg' 'kipinä'.

sm. rankua, ränkyä ronkkua $\leftarrow$ lt. krankti 'vaakkua; korista, kuorsata' (Kim 2015: 136-138; ennen arvioimaton etymologia).

Toisin kuin yllä käsitellyt lintujen ja sirkkojen nimet, tämä sanue on myös nykykäytöltään onomatopoieettinen. Siihen kuuluvat sm. (itämurteet) rankua 'raakkua; mankua', (suomen itämurteista vepsään) ränkyä 'karjua, rääkyä, parkua' ja (suomen itä- ja pohjoismurteitten sekä karjalan) ronkkua 'raakkua'. Samaa alkuperää voi olla myös vi. ronk : rongu, li. kronk 'korppi', joka käytöltään kuuluu jo normaalisanastoon kuten vaikkapa sm harakka.

Onomatopoieettisesti käytettyjen sanojen kulkeutuminen kielestä toiseen on mahdollista siinä missä muunkin sanaston. Kieleen juurruttuaan ne yhtäältä pyrkivät säilyttämään ikonisuutensa vastustamalla sitä uhkaavia äänteenmuutoksia kuten harakka (ikoninen nativisaatio). Toisaalta onomatopoieettiset sanat ovat yleensä merkitykseltään affektiivisia ja pyrkivät myös säilyttämään affektinsa omaksumalla kielessä tuoreita ja ilmaisuvoimaisia fonotaktisia piirteitä (affektiivinen alienaatio), joihin itämerensuomessa ovat kuuluneet (C)VRKKV-tavurakenne (ronkkua), $i$-vartalo (vi. ronk) ja sananalkuiset konsonanttiyhtymät (li. kronk). Niinpä verbipesyeen rankua, ränkyä ja ronkkua äänteellinen variaatio on täysin odotuksenmukaista ja osoitus pikemminkin pitkästä kuin lyhyestä historiasta. Koska onomatopoieettisten lainojen tutkimusta on tehty varsin vähän, ei tämänkään etymologian todennäköisyydestä ole paljon enempää sanottavissa.

sm. synkeä, ka. synkie sm. synkkä $\leftarrow$ 1t. sunkus 'raskas' (Uotila 1992: 171-172)

Konsonanttivaihtelun selitys adjektiiviparissa synkeä $\sim$ synkkä on ilmeinen. Kymmenillä itämerensuomen adjektiiveilla on rinnakkaiset variantit, joista toinen on muodostettu ikivanhalla et $A$-johtimella ja toinen nuoremmalla $k k A$-johtimella (Rauhala 2014). Vanhana balttilaislainana adjektiivi on kuulunut jo kantasuomeen, joten *sünketä > synkeä on sen ensisijainen asu ja synkkä selittyy myöhemmän morfologisen uudelleenhahmottamisen ja siitä johtuneen suffiksinvaihdon tulokseksi (Junttila 2015b: 142).

SSA:n mukaan "merk. ja käyttöyhteydet ovat siinä määrin läheisiä ja synonyymisia sanoille sankka, sankea (esim. merk:n 'raskas' perusteluina esitetyt itämurt. esimerkit synkkä savu, s. sumu sekä merk. 'tiheä (metsä)'), että kyseessä voi yhtä 
hyvin olla näiden etuvok. variantti”. Koska itämerensuomessa ei tunnetusti esiinny mitään säännöllistä, äänteenmuutoksesta syntynyttä $a \sim \ddot{u}$-vaihtelua, on SSA:n mainitsema "varianttisuus" tulkittava synkroniseksi. Adjektiivin synkeä alkuperää voi "variantin" sankea olemassaolo selittää vain siltä osin, että aiempi perintösana on balttilaista adjektiivia muodoltaan ja merkitykseltään läheisenä tukenut sen lainautumista ja juurtumista kieleen (vrt. Kulonen 1996: 30-31).

ve. kurdiž, va. kurre $\sim$ vi. kurt, vs. kurt' 'kuuro' $\leftarrow$ lt. kurčias id. (GSI 80)

Adjektiivi kuuro näyttää olleen erittäin ekspressiivinen päätellen kaikesta epäsäännöllisestä äännevaihtelusta, jota sen merkitysvastineilla on itämerensuomessa ja balttilaisissa kielissä: sm. kuuro $\sim$ kuurne $\sim$ kuurnes $\sim$ kuurna, ka. kuurnis (kuurnehe-) kuurneh $\sim$ kuuris $\sim$ kuunis, ly. kuurniz $\sim$ kuurniš, ve. kurdiž (: kurdho-), va. kurrõ (: kurtõõ-), vi. kurt (: kurdi), vs. kurt'; lv. kurlis $\sim$ kurls $\sim$ kurns $\sim$ kursls $\sim$ 1t. kurčias $\sim$ kurtas (SSA). Kuten jo Setälä (1891: 310) on ehdottanut, vepsän ja eteläisen itämerensuomen muodot (paitsi li. kurli $\leftarrow$ lv. kurls) palautuvat varmaankin $r t$ :1liseen balttilaiseen lähtöasuun, muut pohjoiset muodot $r n$ :lliseen. Tämä ei kuitenkaan selitä pois kaikkea äännevaihtelua. Ensinnäkin suomen kuuro ei ole mitenkään säännönmukainen: ainakin lounaismurteissa odottaisi **kurn-alkuista muotoa, jossa $u$ ei ole pidennyt, kuten idempänä on $r n$-yhtymän edellä käynyt. Kuuro voi olla lainaa niistä livvin murteista, jossa $r n>r$ pitkän tavun jälkeen on säännöllinen äännekehitys (Kalima 1923-24b: 165).

Toisaalta -rt-muoto on säilynyt odotuksenmukaisessa asussa vain vepsässä ja vatjassa. Niitten vastine virossa olisi *kurre $(s)$, kun taas vi. kurt ja vs. kurt' palautuvat asuun *kurtti. Mitään sopivaa lainanlähdettä viron ja eteläviron muodoille ei löydy - esimerkiksi lätissä ei ole (ME:1lä) *kurt-alkuisia muotoja - joten ainoaksi selitykseksi jää suffiksinvaihto jonkin tai joittenkin -tti-päätteisten sanojen vaikutuksesta. Ainoa sopiva vaikutuslähde on viron, vatjan ja inkeroisen *kurtta-kantainen verbi, jolla on kahdenlaisia merkityksiä: yhtäältä 'valittaa', toisaalta 'lakastua, surkastua, riutua': ink. kurttaa 'valittaa; kärsiä', va. kurtta 'valittaa; riutua, surkastua', vi. kurtma, kurtama 'valittaa' $\sim$ kurtuma 'surra', kurtuma $\sim$ kurtama $\sim$ kurtima $\sim$ kurptuma kurduma 'laihtua, lakastua, näivettyä, surkastua; sammua'. Kuurous on varmaankin yhdistetty fyysisen näivettymisen ja surkastumisen merkityksiin, liittyyhän kuuroutuminen useimmiten vanhuuden vaivoihin. Hanilan pitäjästä on kirjattu kurtuma myös merkityksessä 'kuuroutua', mikä osoittaa 'kuuro' ja 'kärsiä, surkastua' -sanueitten vaikuttaneen toistensa merkitykseen. Täten äänteellinenkin vaikutus on todennäköinen. ${ }^{8}$

Vaba (2004) tarkastelee 'kärsimistä, surkastumista' ym. merkitseviä muotoja erillään 'valittamista' merkitsevistä ja on esittänyt niille balttilaisen etymologian,

8. Häädemeesten kurtuma 'surra' ja Keilan kurptuma 'heiketä' lienevät puolestaan saaneet äänteellistä ja merkitysvaikutusta adjektiivilta kurb 'surullinen', pohjoisviron itäosassa tavallinen kurtuma 'sammua' taas verbiltä kustuma 'sammua'. 
joka ei kuitenkaan ole saanut kannatusta. Ehdotuksessa onkin äänteellinen ongelma, oletettujen lähtömuotojen *skurd-> 1t. skursti 'riutua, kituuttaa' ja *gurd-> 1t. gursti 'heiketä; pilaantua; menehtyä' soinnillinen klusiili. Vaba kuitenkin mainitsee samassa yhteydessä venäjän Nižni Novgorodin murteesta tavatun verbin kurtat' 'sairastaa, olla sairaalloinen', jolla on vastine myös serbokroaatissa, krtav 'kuihtunut, surkastunut, näivettynyt'. Samaa kantaa ovat Vasmerin (REW) mainitsemat ven. кopmems 'tuntea kipua; toivoa hartaasti', srb-kro. krtiti 'kiusata, rääkätä' ym. Muinaisvenäjän tasolla verbivartalo palautuu muotoon * $\kappa$ ъpm-. Ilmeisesti juuri tämä on kummankin eteläisen itämerensuomen *kurtta-kantaisen verbin lainanlähde. ${ }^{9}$ Luultavasti 'kivun kärsimisen' lähtömerkityksestä on kehittynyt sekä 'surkastua, riutua' että 'toivoa hartaasti, valittaa' jo lainanantajakielessä.

sm. malka vi. vs. malk, vi. malakas, li. mālka $\leftarrow$ lt. malka 'halko, polttopuut, halkopino' (Donner 1884: 267)

Suomen malka on kirjattu kaikilta murrealueilta. Valosen ja Vuoriston (1994) mukaan "malat olivat pienehköjä, pyöreitä kuusen ja männyn runkoja, jotka asetettiin tuohikatolle painoksi estämään tuohilevyjen käpertymistä ja tuulessa paikoiltaan siirtymistä. Ne ladottiin vieretysten katon poikkisuuntaan harjalta räystäälle." Suomen sanalla on rinnakkaismuoto malko, jonka ohella on Kärsämäeltä kirjattu kokonaan klusiiliton muoto malo, joka lienee sekundaarinen heikon asteen yleistymä. Sana on yleisitämerensuomalainen, mutta viron (malk), eteläviron (malk) ja liivin (mālka) muodoissa yksittäisklusiilin sijalla on (kaikkien näitten kielten ortografioissa - $k$-lla merkittävä) geminaatta. SSA:n mukaan sana merkitsee kaikkialla itämerensuomessa sekä tuohi- tai olkikaton että heinäsuovan tai -keon painopuuta. Suomesta mainitaan myös merkitys 'salko', lyydistä 'pellavalikopuu', vepsästä 'uppotukki', virosta 'kalikka, kurikka' ja liivistä 'riuku'. Pohjoissaameen sanasta on lainautunut málga 'nuori mänty, jossa on runsaasti pintapuuta' ja ruotsin murteisiin malkko 'kattomalka'. Suomen sanasta on johdettu vielä työvälineen nimi malkuri 'suuri leveäteräinen kaira, jolla tehdään reikiä malkoihin ja hirsiin' sekä edelleen yleinen adverbi ylimalkaan 'yleensä, ylipäänsä'.

Donnerista (1884: 267) lähtien on malkaa pidetty vanhana balttilaisena lainana. Rinnastuksessa on kuitenkin semanttinen ongelma, jonka on nostanut esiin vain Nieminen (1963: 234-235). Latvian malka tarkoittaa nimittäin ainoastaan halkoa, liettuan malka lähinnä halkopinoa tai metaforisesti muutakin pinoa. Muinaispreussin malko (kirj. nalko, Grunau 43) on käännetty 'Holz', mutta luultavasti senkin merkitys on ollut juuri 'halko', sillä balttilaisen sanan etymologia liittyy Fraenkelin (LEW) mukaan halkaisemista merkitsevään verbiin: "Am glaublichsten scheint mir Jägers' Anknüpfung 24 von lit. malka etc. an lett. smalks 'fein, subtil, in kleinen Teilen', dazu

9. Itämerensuomessa on kolmaskin *kurtta-kantainen verbi, joka kuitenkin esiintyy vain liivissä ja eteläviron Mulkin murteessa: li. kurtty : kūrtab, Sal. kurt : kūrtub 'pysyä, asettua aloilleen', vs. M kurtma : kurda- 'pysyä, jäädä'. Kettunen (LW 168) esittää sen mahdollisena lainana lätin verbistä kurt : kura 'tehdä tuli'. Mahdollisesti Kettunen on tässä ajatellut lähtömerkitystä 'leiriytyä', mutta lainaverbiin tulisi tällöin muodon selittämiseksi liittää itämerensuomalainen kausatiivijohdin - ttA-, joka taas sopii huonosti lainan intransitiiviseen merkitykseen. 
lit. smulkus 'fein, dünn' usw. Jegers verweist an der Hand einer Belegstelle darauf, daß lett. malka fast immer von zerspaltenem Holz gebraucht wird." Kattomalka taas saatiin pienestä puusta joko halkaisemalla tai vain oksimalla. Ei tunnu järkeenkäyvältä, että kokonaisesta ohuesta rungosta saatua painopuuta tai riukua merkitsemään olisi lainattu halkoa tarkoittava sana. Itämerensuomessa vain liivin $m \bar{a} l k a$-sanalla on lisämerkitys 'halko', joka selittyy myöhäisenä lättiläisvaikutuksena.

Nieminen (mt.) ehdottaa, että malka on lainautunut jostain balttilaisen sanan johdoksesta, ja tuo esimerkiksi liettuan sanan malksna 'paanu', vrt. malksnu stogas 'paanukatto'. Nieminen siteeraa Gimbutasia, jonka mukaan baltit käyttivät kattomateriaalinansa alun perin kaarnaa, sittemmin lautoja. Paanu ei kuitenkaan ole kaarnanpala eikä lauta, vaan VRS:n sanoin "paksuhko, joko lauta-aihiosta tai rungosta lohkomalla, veistämällä, sahaamalla tai höyläämällä valmistettu kattamiseen tarkoitettu jäykkä puukappale, joka on muotoiltu kiilamaiseksi siten, että se paksunee näkyville tulevaa kärkeä kohden.” Näin on ymmärrettävää, että paanun nimitys liettuassa on johdettu halkoa tarkoittavasta sanasta. Kattomalka taas ei ole osa katteen rakennetta niin kuin paanu paanukatossa, vaan toimii ainoastaan rakennetta koossa pitävänä painona. Paanun nimityksen metaforinen siirtymä kattomalan nimeksi ei ole kronologisestikaan uskottavaa, sillä paanukaton rakentaminen vaatii enemmän työtä ja kehittyneempiä työvälineitä kuin malkakaton. Valosen ja Vuoriston (1994) mukaan "paanu sanan esiintyminen ensin Länsi-Suomen murteissa osoittaa tämän taidon tulleen Ruotsin kautta [ru. spån] kirkollisen kulttuurin mukana".

Malan alkuperä löytynee seuraamalla balttilaisia johdossuhteita aivan vastakkaiseen suuntaan. Fraenkelin mainitsema lv. smalks 'hieno, ohut, hienostunut' sopii hyvin itämerensuomen sanan lähtömuodoksi, ovathan malat pienehköjä, ohuita runkoja. Tästä sanasta on voinut kantasuomeen lainautua *malka 'ohut (puunrunko)', josta kielialueen eteläosassa on suffiksinvaihdon kautta syntynyt *malkka ennen sanan substantiivistumista (vrt. * sünketä > synkkä yllä). Suffiksinvaihdon kautta on muodostunut myös pohjoisviron malk-sanan synonyymi malakas.

Selitys on siltä osin hypoteettinen, ettei sanan adjektiivisesta käytöstä ole mitään näyttöä. Oletetun *malkka-adjektiivin johdos voi kuitenkin olla Kymenlaakson murteen malkaista 'laimentaa (lääkettä)' (Kymi), 'laimentaa (väkevää kahvia t. viinaa)' (Virolahti), 'ohentaa (velliä)' (Elimäki), 'laimentaa, heikentää (makua tai vaikutusta)' (Anjala, Elimäki, Vehkalahti), '(tupakka) vähentää ruokahalua' (Kymi), '(tuuli) viilentää (hellettä)' (Elimäki, Sippola), '(auringonpaiste) leudontaa (pakkasta)' (Lapinjärvi), 'auttaa, tulla neuvoksi' (Kymi, Valkeala). Näyttää todennäköiseltä, että malkaista on muodostunut merkityksessä 'ohentaa'. Tämän perusmerkityksen abstraktis-pejoratiivisia jatkokehittymiä saattavat olla myös harvinaisehkot, Hämeestä ja Laatokan Karjalasta kirjatut merkinnät malkaista 'karkottaa' (Eräjärvi; ilman lauseyhteyttä kirjattuna kenties väärintulkinta), 'halveksia' (Hattula), 'masentaa, aliarvioida, halveksia' (Akaa), 'lannistaa' (Parikkala) ja 'harmittaa' (Kirvu; myös malkoa 'vaivata, harmittaa') ehkä myös Keski-Suomesta ja Länsi-Savosta muistiin pantu malkuttaa 'kaivella mieltä, harmittaa'. 
sm. kurponen $\sim$ kurpponen 'tietynlainen kenkä' $\leftarrow$ lt. kurpe், lv. kurpe, pr. kurpe 'kenkä' (Donner 1884: 269)

Erilaisia varrettomia, usein huonoja jalkineita merkitsevässä suomen murteitten sanassa kurpponen $\sim$ kurponen, kurpunen näyttää geminaatta olevan ensisijainen. Nikkilä (1982: 254) on pitänyt sitä tässäkin sanassa pidentymän tuloksena, mutta Nikkilän ja SSA:n mainitsemat yksittäiskonsonanttiset muodot on tavattu vain Jusleniuksen ja Lönnrotin sanakirjoista. Ne edustanevat heikkoasteisia, sittem-

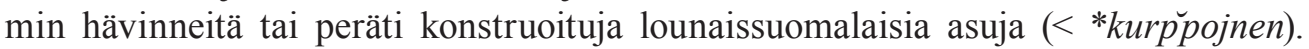
Murteista on merkitty muistiin asut kurpponen, kurpokas, kurppo, kurppunen, kurpukka, kurppa, kurppana, kurppanen, kurppi ja kurpikas. Sana kuuluu lähinnä suomen itä- ja pohjoismurteisiin sekä inkeroiseen: lisäksi viron koillisrannikkomurteesta tavataan kurpakingat, jossa -rp- on mksm. -rpp-:n säännönmukainen vastine. Kreevinin kurppa ja liivin kurp taas ovat peruskäsitteitä merkityksessä 'kenkä', joten niitä on syytä pitää lainoina lätin sanasta kurpe 'kenkä'.

SMS:n tietojen mukaan kurpposen yleisin merkitys ei ole 'jalkine', vaan 'huono, ryppyinen tms. esine', mitä SSA pitää sanan kurppu (sm. Haapasaari, Tytärsaari, ka., ve.) 'ryppy, poimu' vaikutuksena. Sanat kurppu ja kurpponen on kuitenkin tavattu eri alueilta. Kurppu saattaakin alun perin olla kurpposen rinnakkaisasu, jonka merkitys on pejoratiivistunut venäläislainan kurttu vaikutuksesta. Vain levikkialueen länsilaidalla on säilynyt varhaisin 'jalkineen' merkitys, johon siihenkin on voinut pejoratiivistavasti vaikuttaa kurttu. Varmaankin kurpposen mallin mukaan on muodostettu sm. (Päijät-Häme, Savo, Vermlanti, Satakunta) karpponen 'lumikenkä, suokenkä' sanasta karppa 'jäätynyt lumenkuori, routainen maanpinta'.

Kantasuomen balttilaisperäisessä sanastossa ei ole muita vaatteitten tai jalkineitten nimiä kuin kinnas; samaan aihepiiriin liittyvät tosin myös rihma, talja ja vuota. Muotivirtaukset ja valmistustekniikat ovat aika ajoin uudistaneet alan sanastoa, joten siihen kuuluu enimmäkseen nuorempia lainoja. Myös levikistä päätellen kurpponen murrevariantteineen onkin vasta muinaiskarjalan mukana levinnyt venäläislaina. Sen lähtömuotona voi olla SSA:n mainitsema Pihkovan ja Tverin murteitten kúrpy, kurpíny 'hamppunuorasta valmistetut miesten kengät', joka on lainattu kurpposenkin lähtömuotona pidetystä liettuan kurpe-sanasta. Toisaalta Smoczyński (SEJL) mainitsee liettuan sanalle myös suoria vastineita slaavilaisista kielistä: srbkro. krplje 'vanhat kengät; lumikengät', pl. kierpce 'virsujen tapaiset perinteiset nahkajalkineet'. Niitä on myös muinaisvenäjässä voinut vastata sittemmin kadonnut

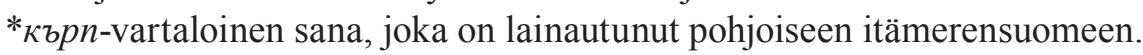




\section{Edustus resonantin jäljessä: geminaattatapaukset}

Vahvassa asteessa yksinomaisen geminaatan tapauksista lähes puolet on $i$-vartaloisia: sm. karppi, lorppi, pirtti, vi. kärpima 'karsia, teroittaa' sekä vs. mulk' 'mulkinmaalainen', virp' 'vyyhteämisvirhe' ja ärk' 'puutiainen'. Kaikki $i$-vartalot lienevät syntyneet vasta keskikantasuomen kauden jälkeen, vaikka osa niistä on johdoksia sittemmin kadonneista sanoista kuten esimerkiksi balttilaisperäinen keli $(\Leftarrow * k e l j a ̈$, Nieminen 1944: 249). Niitten jälkeen tarkastelen kolmea sanaa, joitten äänteellinen suhde ehdotetun balttilaisen lainanlähteen kanssa on hyvin ongelmallinen: sm. karttu, kärppä ja varttua 'väsyä'. Muut tässä käsiteltävät sanat ovat sm. karppa, kartta, porkkana, vi. mülgas 'suonsilmäke' ja erk 'valpas'.

sm. karppi 'puinen laatikko, rasia' $\leftarrow$ lv. kārpe 'puinen kirstu' (Donner 1884: 269)

Karppi esiintyy suomessa vain Suomenlahden saarten ja Inkerinmaan murteissa, joihin se on varmasti levinnyt virosta, kuten monet muutkin levikiltään samanlaiset sanat. Eteläisessä itämerensuomessa sana on tavallinen (va. karppi, vi. karp, vs. karp', li. kaŗp $\sim$ kärp). Viron sanalla on murteissa merkitykset 'väike madalavõitu puust, papist vm (kaanega) kast(ike), toos; ümmargune või pikergune puust (hv tohust) kaanega nõu toidu hoidmiseks ja kaasavõtmiseks; sahtel; kummut; kirst (panipaik); sumadan, kohver; lindude pesakast; limuste koda' (EMS). Sanaa on pidetty sekä balttilaisena, slaavilaisena että alasaksilaisena lainana, mutta oletettujen lähtömuotojen levikki ei tue lainaoletuksia. Lätin sanasta kārpa, kārps 'soikea puinen rasia' on murremerkintöjä alueilta, joilla itämerensuomalaiset lainat ovat tavallisia (ME; Zeps 1962: 121). Keskialasaksin karpe 'puinen laatikko' on tavattu vain yhdestä lähteestä Liivinmaalta (MndW; Bentlin 2008: 66). Kiparskyn (1936: 40) mukaan baltiansaksan Karp Karpe 'rasia, pieni laatikko' on kuitenkin ollut käytössä paitsi koko Baltian alueella myös Polatskissa ja Novgorodissa.

Slaavilaisella taholla karppi on yhdistetty venäjän sanaan ко́pобья́ 'kori, kappa, arkku; vanh. (Novgorod 1437) vetomitta', josta on lainautunut myös sm. karpio 'vanha suuruudeltaan vaihteleva (viljan) vetomitta' (BFB 183, SSA s.v. karpio). Ven. ко́робья́ on johdos sanasta ко́роб 'vakka', joka on luultavasti kulkeutunut jonkin germaanisen kielimuodon (vrt. sa. Korb 'kori') kautta latinasta (corbis 'kori'). Itämerensuomalainen karppi ei kuitenkaan merkitse vetomittaa, joten sillä tuskin on välitöntä suhdetta karpio-sanaan. Merkitykseltään paljon lähemmäs tulee кópoбsanan deminutiivi ко́робка 'rasia, laatikko, kotelo'.

Viron murteitten venäläislainoissa sananloppuiset soinnilliset klusiilit edustuvat tavallisesti pitkinä soinnittomina klusiileina: korp : korba 'kyttyrä; kumpu' $\leftarrow$ ven. горб 'kyttyrä', kоrop korup koorup 'reen selkänoja' $\leftarrow$ ven. ко́роб (Must 2000: 126, 495). Karpin ensi tavun $a$ tekee kuitenkin mahdottomaksi selittää itämerensuomen sana lainana venäjän myöhäisistä polnoglasie-muodoista кópoб jа ко́робка. Peipsijärven itärannalta Oudovasta (ven. Gdov) on tavattu $a$-vokaalinen muoto ка́pбик 'pieni kannellinen rasia' (POS), mutta se lienee laina viron deminutiivijohdoksesta 
karbike. Latviaan ven. ко́роб on lainautunut muodossa kārba 'tuohinen astia, rasia; kalastajavene; kattotiili; soikea puinen rasia' (ME), mutta lätin sanansisäinen $b$ edustuu viron latvialaislainoissa $b$ :nä eikä $p$ :nä (esim. vi. murt. kirbits 'kurpitsa' $\leftarrow$ lv. ķirbis id., Vaba 1997: 406) eikä yllä mainittu lv. kārpa levikkinsä takia varmaankaan ole omaperäinen kehittymä asusta $k \bar{a} r b a$, vaikka latviassa sporadista muutosta $b>p$ tavataankin.

Sekä venäläisen että latvialaisen lainaselityksen tekee epätodennäköiseksi itämerensuomalainen $i$-vartalo odotuksenmukaisen $a$-vartalon paikalla. Tällaiset sanat on usein saatu viroon ja sen pienempiin naapurikieliin baltiansaksan välityksellä (esim. pliit : pliidi 'hella' $\leftarrow$ saBa. Pliete $\leftarrow$ ven. nлиma, Hinderling 1981: 28). Luultavasti myös viron karp on saatu alasaksista - kuten jo Ojansuu (1916: 144-145) on epäröiden esittänyt - tai myöhemmästä baltiansaksasta, joissa se puolestaan on slaavilaista lähtöä aivan kuten lätin kārba ja liettuan suunnilleen samanmerkityksinen karbas.

Kiparsky (mt.) vastustaa baltiansaksan sanan Karp $\sim$ Karpe slaavilaista alkuperää, sillä venäjän soinnilliset klusiilit substituoituvat saksassa vastaavilla soinnillisilla klusiileilla. On kuitenkin kaksi mahdollisuutta selittää saksan ja alasaksin sanan - $p$-. Ensinnäkin niitten lähtömuotona voi olla hypoteettinen lv. *kārbs [kārps] $\sim k \bar{a} r b a \leftarrow$ ven., sillä latvian sanastossa horjunta maskuliinin ja feminiinin välillä on yleistä (vrt. kārpa, kārps yllä). Toisaalta ne ovat voineet lainautua muinaisslaavilaisesta deminutiivimuodosta *карбка [karpka]. Lähtökielen deminutiivipääte on tällöin voitu substituoida kohdekielen deminutiivipäätteellä $>$ kas. *karpken, vrt. saBa. Karpchen (WDSL 2 s.v. Karp). Tämä selitys edellyttää lainautumista slaavin redusoi-

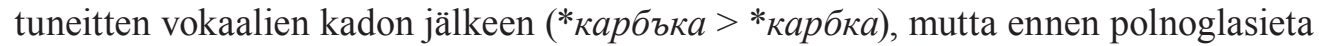
(> ven. ко́робка). Jo 1200-luvun novgorodilaisissa lähteissä esiintyy muoto кópобъ (REW); toisaalta Pihkovan läänin murteessa on 1900-luvulle saakka säilynyt myös muoto корб (POS, s.v. ко́роб).

sm. lorppi lörppi 'laiskuri, tyhmyri' $\leftarrow$ lt. liurbis 'hulttio', lv. ļurba 'juoppo, vetelys, lörppö’ (Būga 1908: 191)

Suomen, lähinnä lounaismurteitten lorpin ekspressiiviseen merkitykseen liittyy odotuksenmukaisesti runsasta äänneasun vaihtelua: SSA mainitsee rinnakkaismuodot lorppo, lorppua, lorkki, lortti, lorvi ja lurppa. Tämän deskriptiivisen pesyeen sisäisiä suhteita ei ole selvitetty, mutta balttilaista alkuperää se ei ole. Ensinnäkään sm. lorppi ei voi vastata liettuan muotoa liurbis vokaalisuhteen takia: kantasuomen aikaisissa balttilaislainoissa kba. ja lt. $u$ :ta vastaa ims. $u$ tai $\ddot{u}$. Toiseksi liettuan sanassa on soinnillinen klusiili.

sm. pirtti $\leftarrow$ lt. pirtis 'sauna' (GSI 83)

Pirtillä pohjoisitämerensuomalaisine vastineineen (ink. pertti, ka. pirtti pertti, ly. pertti, ve. pert' 'tupa, pirtti, asuinhuone t. rakennus; maja'; SSA:n mukaan myös sm. $\rightarrow$ vi. ja ink. $\rightarrow$ va.) on jo Niemisen (1953: 214-217) esittämä slaavilainen lainaselitys. 
Vanhaa balttilaisetymologiaa kuitenkin kannatetaan yhä. Sitä on puolustanut Peterson (1980), joka vetoaa vanhimman hirsirakennussanaston (seinä, kirves ym.) balttilaisperäisyyteen ja itämerensuomalaisten asuinalueilta löydettyjen varhaisten rakennusten korkeaan ikään. Mikään ei kuitenkaan pakota olettamaan, että pirtti olisi vanhin käytössä ollut hirsirakennuksen nimitys, eikä nykykäsityksen mukaan kantasuomeakaan puhuttu Itämeren alueella vielä aikana, jolta vanhimmat hirsirakennusten jäänteet ovat peräisin. Jo Vahros (1966: 61-68) on onnistunut riittävin perustein osoittamaan, että itämerensuomen pirtti on laina liettuan pirtis-sanan muinaisvenäjän vastineesta *nьpmь. Sanalla ei ole vastineita nykyvenäjässä eikä siitä ole kirjallisia merkintöjä, mutta sen olemassaolon todistavat venäjänkirkkoslaavin 'eteistä, kuistia' merkitsevät johdokset nапьрть ja припьрть sekä laina marin kieleen (nöpm 'talo').

vi. kärpima 'karsia, typistää, leikata; teroittaa' Ł lt. kirpti, lv. cirpt 'leikata' (IBL 125-126)

Viron kärpima on Mägisten (1977: 167-168) ja Uibon (2010b: 372-374) mukaan alasaksilainen laina. Mägisten argumentit Kaliman balttilaislainaoletusta vastaan eivät liity sanan äännerakenteeseen vaan semantiikkaan: viron verbi merkitsee nimittäin paitsi 'leikkaamista' ja 'karsimista' myös 'teroittamista', sen lainanlähteenä pidetty lt. kirpti vain 'saksilla leikkaamista'. Mägiste on esittänyt lähtömuodoksi keskialasaksin verbiä scherpen 'teroittaa' ja Uibo tarkentanut, että osa merkityksistä on saatu verbiltä kerven 'karsia, typistää, leikata'. EES taas esittää lähtömuotona vain kerven-verbin.

Äänne-edustus ei Uibon etymologiassa ole aivan odotuksenmukainen, joten on todennäköistä, että jo aiemmin lainatulle viron muodolle on kerven-verbiltä tarttunut vain lisämerkitys. Alkuperäisenä lainanlähteenä voi olla paitsi as. scherpen, myös muutamaa vuosisataa vanhempi skandinaavinen muoto, jota vastaa ruotsissa skärpa 'teroittaa' (LägLoS s.v. kärväs). Muinaisskandinaavin kirjallisista lähteistä ei löydy itse verbiä, vaan ainoastaan sen kantana ollut adjektiivi skarpr 'terävä; kuivettunut; kova'. Viron verbiin liittyvät myös SMS:n mainitsemat yksittäiset esiintymät suomen murteista: kärppiä 'karsia' (SMS Viime yönähä pakkane ol, ku kärppi vähäm potatin varsia. Kangasniemi) ja kärppi ’terävä' (SMS Taipalsaari, Virolahti).

vs. mulk' 'mulkinmaalainen' $\leftarrow$ lv. mullkis 'tyhmyri, hölmö’ (IBL 139)

Viljandimaan eteläosan asukkaista ja murteesta käytettyä nimitystä mulk' (: mulgi) on Kalima (IBL 139) hyvin hatarin perustein harkinnut kantasuomen balttilaislainoihin luokiteltavaksi. Mikroetnonyymien tapaan sana on varmasti suhteellisen nuori: Vaba (2017) ajoittaa sen synnyn 16. vuosisadalle, Lust, Pae ja Saar (2017) vasta 1860-luvulle. Näitten äskeisten tutkimusten perusteella sanan motivaationa on joko henkilönnimi tai laina latviasta.

vs. virp' 'vyyhteämisvirhe; harhakuva' $\leftarrow$ lt. verpti, lv. vērpt 'kehrätä' (Mikkola 1894: 95-96) 
Toisenkin eteläviron sanan balttilaisetymologia on perustelua vailla: Mikkola ja Kalima (IBL 180) yhdistivät sanan virp' 'vyyhteämisvirhe, vyyhdettäessä sotkeentuva lanka' balttilaiseen 'kehräämistä' merkitsevään verbiin (lt. verpti, lv. vērpt). Lankaa on toki pyöritettävä sekä kehrättäessä että vyyhdettäessä, mutta 'sotkeentumisen' merkitystä ei silti voi suoraan johtaa 'kehräämisestä'. Sanalla virp' on myös merkitys 'harha(kuva)', jota Mikkola ei mainitse. Hyvin lähelle sen molempia merkityksiä tulee aivan toinen latvian sanue: virpa 'Wirbel', virpties 'wirbeln', virpināt 'pyörittää, rullata; värisyttää' (ME). Saksan Wirbel on 'pyörre (mm. hiuksissa)' ja verbi wirbeln 'tupruta, tuiskuta, ryöpytä; kuohua; pyöriä; (pass.) olla päästään pyörällä, huimata'. Lätin sanue on samaa kantaa kuin 1t. virpèti 'väristä, täristä' (LEW), mutta liettuan verbiltä ja sen johdoksilta puuttuvat 'pyörimiseen' viittaavat merkitykset. Lätissä ne ovat varmasti saksan wirbeln-verbin vaikutusta. Viimeistään tämä osoittaa myös eteläviron sanan nuoreksi. Se on todennäköisesti lättiläisperäinen, vaikka tarkkaa lähtömuotoa ei löydykään.

\section{vs. Leivu ärk' 'puutiainen' $\leftarrow$ lt. erkè, lv. èrce 'punkki' \\ (Vaba 1992: 459; ennen arvioimaton etymologia)}

Leivun kielisaaresta Pohjois-Latviasta tavattu vs. $\ddot{a r} k^{\prime}$ 'puutiainen' on ainoa $i$-vartaloinen (C)VRCCV-tyypin sana, jonka yhteyttä oletettuun balttilaiseen originaaliinsa ei tässä ole mahdollista kumota. Eteläviron lättiläislainojen kerrostumaankaan se ei sovi, sillä siinä edustuu lätin ja latgalin esimuodon varhaiskeskiaikaista $k, g>c, d z$ -muutosta edeltävä kanta. Samanlainen edustus on eräissä muissakin Vaban (1996) löytämissä balttilaislainoissa, joitten levikki rajoittuu eteläviroon: kihne 'hapahko', kinu 'kumpu', kõno 'hunajankerääjän tikkaat', kähr 'mäyrä' ja käblik 'peukaloinen'. Vaba osoittaa ne kaikki eteläviron, liivin ja viron lättiläislainakerrostumia vanhemmiksi ja lukee ne siten vanhaan, kantasuomen balttilaislainojen kerrostumaan. Periaatteessa ne voisivatkin siihen kuulua, mutta $\ddot{a} r k^{\prime} \leftarrow$ ba. *erkē $\sim$ *erke ei, sillä sen $i$-vartalo edellyttää nuorempaa alkuperää.

Vaban ja eräitten aiempien lainasanatutkijain työn tulosten pohjalta hahmottuu eteläviron sanastosta esiin erillinen muinaislatgalilainen lainasanakerrostuma, joka sijoittuu kantasuomen balttilaislainojen ja historiallisen ajan lättiläislainojen väliin. Edellisestä sitä erottaa lähinnä levikki, jälkimmäisestä äännesuhteet (Junttila 2016b). Vs. $\ddot{r} r k^{\prime}$ antaa aivan uuden argumentin tueksi muinaislatgalilaisen kerrostuman oletukselle: sen äänneasu viittaa selvästi keskikantasuomea nuorempaan lainautumiseen, mutta latviaa arkaaisempaan lähtökielimuotoon. Yhteen lainasanaan tukeutuvana argumentti on toki vain viitteellinen, sillä periaatteessa sanan $\ddot{a} r k^{\prime}<* \ddot{a} r k k i$ loppuosa voi olla sekundaarinen esimerkiksi suffiksinvaihdon tuloksena; jonkin verran sitä kuitenkin tukevat alla esitetyt huomiot vs. kaugas-sanasta.

sm. kärppä $\leftarrow$ ba., vrt. lt. kirbas 'turkispala' kirbys 'turkiseläin'

(Būga 1908: 191) 
Kärppä on itämerensuomalaiselta levikiltään hyvin balttilaisperäiseksi sopiva sana: sillä on vastineet kaikkialla kielialueen eteläosassa ja suomessa. Būgan ehdottamat lähtömuodot, 1t. kirbas 'turkispala' ja siitä johdettu kirbys 'turkiseläin' sopivat myös semantiikaltaan, onhan kärppä haluttu turkiseläin. Etymologia kuitenkin kaatuu äänteellisiin ongelmiin: paitsi soinnillisen klusiilin edustukseen, myös vokaaleihin. Aiemmin on ajateltu ba. -ir-:n voivan edustua ims. -är:nä sanoissa härkä ja kärme (> käärme), mutta kummallekin on olemassa paremmin sopiva -ar-llinen tai -er-llinen lähtömuoto (Liukkonen 1999: 54-56 *žarga, BFB 188 *kermis). Kärpälle ei ole onnistuttu löytämään alkuperänselitystä. Se saattaa siis olla peräisin jostakin jäljettömiin kadonneesta Itämeren alueen kielestä. On mahdollista, että myös liettuan sanojen alkuperä on samalla suunnalla, sillä niitten toistaiseksi ainoa, Fraenkelin (LEW, s.v. kirbas) esittämä etymologia on semanttisesti ongelmallinen. Myös toiselle kärpän nimitykselle portimo on ehdotettu balttilaista lähtömuotoa, mutta sekään tuskin pitää paikkaansa (vrt. Junttila 2012: 268).

sm. karttu 'kepakko, kapula, maila; poikkipuu' $\leftarrow$ lt. skalbtuvé 'pesukarttu' (Ojansuu 1921: 9-10)

Ojansuun mukaan sm. (ink. ka. va.) karttu 'kepakko, kapula, maila; poikkipuu' saattaisi olla lähtöisin balttilaisesta muodosta, jota liettuassa vastaa skalbtuvé 'pesukarttu; pesupaikka; pesula' ( $\Leftarrow$ skalbti 'pestä'. Tämäkin etymologia on äänteellisesti ongelmallinen, sillä ba. -l- ei vastaa ims. -r:ää. Ei ole myöskään varmaa, että kartun lähtömerkitys on ollut 'pesukarttu'. Uskottavaa etymologiaa ei kartulle ole esitetty.

sm. varttua 'väsyä' $\leftarrow$ lv. vārgt 'heiketä, kuihtua, kituuttaa', (Suhonen 1998: 631-632)

Suhonen on ehdottanut balttilaista etymologiaa tälle savolais-kainuulaiselle murresanalle kritisoidessansa Vaban (1997: 238-239) esittämää latvialaislainaselitystä viron suunnilleen samaa merkitsevälle vartuma-verbille. Suhonen on oikeassa siinä, että viron verbin suomen vastine estää sen latvialaisen alkuperän, mutta myös Vaban rinnastus on ongelmallinen. Lv. -g- ei voi missään lainakerrostumassa edustua ims. $t t$ :nä, eikä etymologiaa pelasta Vaban oletus infinitiivin $t$-päätteen edustumisesta osana lainaverbin vartaloa - tällainen lainautuminen on hyvin harvinaista, kuten hän itsekin samassa yhteydessä myöntää. Paljon luontevampi on Suhosen esittämä vaihtoehtoinen selitys: sekä viron että suomen verbin merkitys 'väsyä' on kehittynyt yleisitämerensuomalaisen, germaanisperäisen verbin varttua 'odottaa' perusmerkityksestä.

sm. karppa 'lumenkuori, routainen maa ym.; noki', li. kārpa 'syylä, varpaan känsä' Ł lt. karpa 'syylä' (Anderson 1879: 196-197)

Anderson (mt.) ja Donner (1884: 267) ovat ehdottaneet liivin sanaa kārpa 'syylä' lainaksi liettuan samanmerkityksisestä sanasta karpa. SSA esittää liivin sanan 
vastineena suomen lounaismurteitten sanalle karppa 'jäätynyt lumenkuori, kovettunut routainen maanpinta; lihan pinnalle noussut suolakerros; karsta, noki' ja viron sanalla karp (: karba) 'puun kuori (irrotettuna); likakerros; känsä, rohtuma, rupi'. Tämä on Asko Vilkunan (1965: 23) esittämän mukaan laina ruotsin adjektiivista skarp, joka 'terävän' ohella merkitsee myös 'kuiva, kuivattu, nahistunut, kova'. SSA pitää koko pesyettä skandinaavisena lainana, mutta Vaba 1990: 129, 2011a: 757) balttilaisena. SSA:n mukaan lätin kārpa 'syylä' on lainaa liivistä, mutta Fraenkelin (LEW s.v. karpa) mukaan liettuan sanan vastine.

Kuten Fraenkel esittää, liettuan ja latvian 'syylää' merkitsevät sanat liittyvät yhteen ja niillä on myös germaanisia vastineita, (mm. sa. Schorf'rupi'). Liivin kārpa on siis lättiläinen laina, kuten jo Suhonen (1973: 127) on päätellyt. Viron karp ja suomen lounaismurteitten karppa ovat toista sanuetta, vaikka viron sanan merkityksiin 'känsä, rohtuma, rupi' on lv. kārpa voinut vaikuttaa. Karpan lähtömuotona voi olla skandinaavinen adjektiivi vain, jos se on lainautuessa substantiivistunut (vrt. LägLoS). Skandinaavinen alkuperä sopisi myös sanan läntiseen levikkiin. Toisaalta merkityksen puolesta parempi lähtömuoto olisi mven. *скоруnа 'kuori', jonka Vasmer (REW s.v. скорлупа) on rekonstruoinut sanan скора 'iho' johdoksena.

sm. kartta 'kaukalo' $\leftarrow$ ba. *karta, vrt. 1t. prakartas, pr. pracartis id.

(Mikkola 1894: 127)

Kartta 'kaukalo' esiintyy suomen Pohjois-Karjalan murteissa, eteläkarjalassa ja livvissä. Sana on silloin tällöin, Mikkolasta lähtien yhdistetty mieluummin balttilaisiin sanoihin 1t. prakartas, pr. pracartis 'kaukalo' kuin venäjän samanmerkityksiseen sanaan кopbımo. Pääsyynä on slaavilaisetymologian äänteellinen ongelma: toisen tavun pääpainollinen vokaali näyttää jäävän edustumatta lainassa. Täytynee olettaa, että aiempi muoto *karutta on lyhennyt epäsäännöllisesti. Paralleelin tarjoaa sm. karppa $<*$ karuppa $\leftarrow$ mven. *ккоруna (vrt. yllä), jos se osoittautuu slaavilaiseksi lainaksi. Vasmer (REW) esittää balttilaiset sanat (< kba. *pra|karta-) venäjän sanojen vastineina, mutta ne eivät esiinny ilman prefiksiä 'kaukalon' merkityksessä.

sm. porkkana $\leftarrow$ 1t. burkantai 'palsternakka', lv. burkāns 'porkkana'

(Donner 1884: 266)

Porkkanan balttilaisetymologian tekee epätodennäköiseksi paitsi vokaalisuhde ims. $o$ $\sim$ ba. $u$, myös syötävän porkkanan lyhyt historia näillä main: porkkananviljely yleistyi Pohjois-Euroopassa vasta myöhäiskeskiajalla (RGA 20 2002: 134, Bentlin 2008: 246-249). Olen äskettäin (Junttila 2014: 130-131) lyhyesti maininnut sanalle uuden selityksen. Uuteen ruokakasviin tutustuttiin varmaankin hansakaupan välittämänä tuontitavarana vaurastuvasta Länsi-Euroopasta, kenties Alankomaista, jossa sitä viljeltiin jo laajalti. Juures nimettiin sen kuvitellun lähtömaan, maineikkaan Burgundin, sa. Burgund, holl. Bourgondië, ruhtinaskunnan mukaan. Mahdollisesti juuri hansakauppiaat keksivät brändätä kauppatavaransa 'burgundilaiseksi' sen prestiisiä 
kohottaakseen. Burgundin nimen keskialasaksinkielinen muoto selittäisi porkkanan nimitykset niin Baltian saksassa - Borkane $\sim$ Burkane -, venäjän murteissa - бурка́н $\sim$ борка́н барка́н -, lätissä - burkāns - kuin itämerensuomessakin - esim. sm. ka. porkkana, vi. porgand, li. borkyn ja vs. põrk'nas põrg'nas. Keskialasaksin brakannie brackannye 'palsternakka, porkkana' lienee myös samaa alkuperää, mutta on jostain syystä äänteellisesti muuntunut. Burgundiin liittyy jotain kautta myös unkarin sanan burgonya 'peruna' alkuperä (TESz).

Äänneasujen runsasta kielittäistä ja murteittaista variointia voi selittää vaikutus venäjän sanoista морковь 'porkkana' ja бурак 'punajuuri'. Ainakin Aunuksen karjalassa porkkanaksi kutsutaan sekä punajuurta että monta muutakin mötikkämäistä kasvia tai kasvinosaa: punajuurta, peltoretikkaa sekä lumpeen tai ulpukan kukkaa. Parhaiten paikannimiperäisyys näkyy viron muodossa porgand sekä sille äänteellisesti hyvin läheisessä liettuan sanassa burkantas 'palsternakka'. Burkantas on käytössä myös miehennimenä, mikä tukee oletustani sanan alkuperästä, sillä lapsia nimetään usein kansallisuuksien mutta harvoin juuresten mukaan. Muitten kielten alveolaariklusiilittomat asut ovat luultavasti venäjän murteitten kautta kiertäneitä lainoja, mitä tukee SSA:n maininta sanan myöhäisyydestä suomen länsimurteissa.

vi. mülgas 'suonsilmäke, hete' $\leftarrow$ ba. *mukl-, vrt. 1t. muklus 'soinen; upottava, mutainen (tie)', lv. muklains 'soinen' t. $\leftarrow$ ba. *mVlk, vrt. slov. mlaka 'lammikko, lätäkkö’ (Vaba 1989: 211-213)

Viron sanalla mülgas : mülka 'suonsilmä, suonsilmäke, hete, kulju' on vastine myös etelävirossa, mülge $\sim$ mülgäs $\sim$ mülgätüs id. Viron murteissa on myös muodot mulgas, mölgas, mülde, müldatus ja mülgässik, Wiedemannin sanakirjassa mülk : mülgü. Vaba esittää sanalle kahta vaihtoehtoista etymologiaa. Se voisi olla lainaa joko balttilaisesta *mukl-kannasta, vrt. 1t. muklus 'soinen; upottava, mutainen (tie)', lv. muklains 'soinen' tai *malk-kannasta, jolla on vastineet useimmissa slaavilaisissa kielissä, esim. mven. молокита, slov. mlaka 'lammikko, lätäkkö'.

Ensin mainitun selityksen ongelma on sen edellyttämä metateesi $k l>l k$, jollaista balttilaislainoista ei tavata. Virossa kantasuomen $\mathrm{kl}$-yhtymät ovat muuttuneet $\mathrm{Vl}$-ksi (esim. ksm. *nakla > vi. nael 'naula'), joten mülgas voisi periaatteessa olla tämän muutoksen jälkeinen latvialaislaina, joka virosta olisi lainautunut edelleen eteläviroon. Rinnakkaismuodot mülge ja mülgätüs ovat kuitenkin hyvin yleisiä etelävirossa, jossa $-k l$-yhtymä on säilynyt (muodossa $-g l$-), joten levikki ei tue tämän suuntaista leviämistä. Toinen esitetty lähtömuoto, ba. *malk- > ksl. *molk-> sl. молок- малкei sovi ensi tavun vokaalin puolesta: tulisi olettaa tyhjäasteinen apofoniamuoto ba. *mulk- > sl. *

Vaba (mt.) liittää mülgas-pesyeen balttilaiseen lähtömuotoon myös eteläisen itämerensuomen *mulkku-sanueen: vi. mulk 'reikä, aukko', li. mulk 'veräjä', jolla Vaban mukaan on myös etuvokaalinen variantti pohjoisessa itämerensuomessa, ka. mylkky mylkäs ( ly., ve.) 'perse'. SSA:n mukaan myös Martin lainsuomennoksessa (n. 1580) esiintyy mulkku 'veräjä' (mahd. myös = sm. mulkku 'kivekset'). Kaikkien 
näitten sanojen yhteenkuuluvuus on luultavaa, sillä etuvokaalisten varianttien syntyminen etenkin affektiivisille sanoille on itämerensuomessa ollut varsin tavallinen ilmiö (vrt. esim. Hahmo 1996: 54, Kivinen 2007: 64). Sanue jää kuitenkin toistaiseksi ilman luotettavaa etymologiaa.

vi. erk : erga 'valpas; kirkas; eloisa' $\leftarrow$ ba., vrt. ven. зоркиŭ 'terävänäköinen' (Junttila \& al. 2015; ennen arvioimaton etymologia)

Tämä etymologia perustuu Madis Arukasken Tarton yliopiston etymologiatyöpajassa 7.11.2015 esittämään huomioon venäjän adjektiivin зоркий balttilaisen kantavartalon *žerk $\sim * \check{z} a r k$ - ja viron adjektiivin erk välillä. Suhtauduin rinnastukseen tuolloin innostuneesti, mutta sittemmin olen EMS:n anteita vertailemalla havainnut, että adjektiiveilla ere : ereda (= vs. herre) ja erk (= vs. herk) on viron murteissa toisin kuin kirjakielessä - kaikki samat päämerkitykset. Näin ollen vi. erk $<$ ksm. *herkkä on varmasti adjektiiveille tyypillisen suffiksivaihtelun kautta syntynyt muodosta *heretä (> vi. ere). Lähemmin tarkastellen löytyy viron murteista kaksi homonyymistä adjektiivia: yksi merkityksessä 'kirkas, helakka; kuuma, polttava' ja toinen 'herkkä, kärsimätön; reipas, äreä'. Edellisen olen samassa yhteydessä ehdottanut lainautuneen siitä balttilaisesta kannasta, jota liettuassa vastaa žéreti 'loistaa' (vrt. myös Junttila 2015b: 220), jälkimmäinen taas on suomen herkkä-sanan vastine (vrt. SSA).

\section{Edustus pitkän vokaaliaineksen jäljessä: yksittäisklusiilitapaukset}

Keskikantasuomesta periytyvät pitkät vokaaliainekset voidaan jakaa alkuperältään kolmeen ryhmään: pidentyneisiin, kahden tavun yhtyessä eli supistumateitse muodostuneisiin sekä vokaalin ja puolivokaalin $(j, w)$ yhtymästä syntyneisiin (Aikio 2012; vrt. myös tämän artikkelin I osa s. 128). Ensimmäiseen ryhmään kuuluu osa pitkistä $e e$ - ja $o o$-vokaaleista ( $>\mathrm{sm}$. ie, uo) sekä mahdollisesti eräät $i i$ - ja $u u$-vokaalit, toiseen ryhmään monenlaisia pitkiä vokaaleita ja diftongeita, kolmanteen pääosa diftongeista sekä osa $i i$ - ja $u u$-vokaaleista. Lisäksi joissakin jo keskikantasuomeen saaduissa lainasanoissa on sellaisenaan lainautunut pitkä vokaali tai diftongi: näitä ovat todistettavasti sellaiset $e e$ - ja $o o$-vokaaliset sanat, joissa pitkää vokaalia seuraa jokin muu konsonantti kuin vokaalinpidennyksen aiheuttanut $m, n, l, r$ tai $\left(\delta, \delta^{\prime}>\right) t$.

Keskikantasuomen pitkää vokaaliainesta seuraa vokaalienvälinen klusiili 43 sanassa, jolle on esitetty ja kannatettu balttilaista lainaetymologiaa. Varmasti balttilaisperäisiä näistä ovat sm. heitiä heisipuu, joutaa, lauta, leuka, lieve, liika, luuta, niisi, nuode 'puolison sukulainen', nuutua, pouta, reikä, reisi, routa, seipi, seiväs, siikanen 'vihne', veikeä ja vuota sekä ainakin jotkin sanoista sm. hauki, hautoa, kaivata, kaukalo, kouko 'aave; suurpeto; täi', laito 'matala vesi', laukea, paukama, rauta, 
ruoko, vaidella 'pyydellä, valittaa', viikate, vi. õis(vesi) 'haavan erite', li. kȳidas 'kangasharja' ja lȳiga 'liika' sekä vs. kuvvas (: kuuda) 'kirveenvarsi'. ${ }^{10}$

Näistä 10-21 sanan balttilaisessa lähtömuodossa ${ }^{11}$ on soinniton klusiili: sm. hauki $\left(? \leftarrow{ }^{*}\right.$ šeuk $\left.\mid \bar{a}\right)$, hautoa $\left(? \leftarrow{ }^{*}\right.$ šaut- $)$, kaukalo $\left(? \leftarrow{ }^{*} k a u k \mid \bar{a} l-\right)$, kouko $(? \leftarrow$ *kauk|as), laito $(? \leftarrow$ *šlait $\mid a)$, laukea $(? \leftarrow$ *lauk-), lauta $(\leftarrow *$ plaut $\mid a)$, leuka $(\leftarrow$ *kleuk $\mid \bar{a})$, lieve $(\leftarrow * k l e \bar{p} \mid$ ijas, ellei soinnillinen *klēb|ijas), liika $(\leftarrow * l e i k \mid a \sim-\bar{a})$, luuta

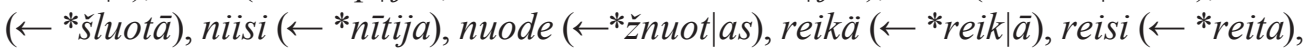
seipi $\left(\leftarrow *^{*}\right.$ steip-), veikeä $\left(\leftarrow *\right.$ veik-), viikate $(? \leftarrow * i z ̌|k a p t| i s)$, li. kȳidas $\left(? \leftarrow *^{*}\right.$ skeit $\mid$ as $)$ ja lÿiga $(? \leftarrow$ *leika) sekä vs. kuvvas $(? \leftarrow$ *kātas $)$.

Vielä arvioimaton balttilaisetymologia on esitetty äännerakenteeltaan vastaavanlaiselle sanalle sm. raukua, räykyä 'valittaa; pyytää, mankua' $\leftarrow$ lt. kraukti 'raakkua' (Kim 2015: 136-138), mutta suuren merkityseron vuoksi on sitä pidettävä hyvin epävarmana. Lisäksi Hahmo (2001: 278) on esittänyt, että sm. laude saattaa palautua erillislainana samaan balttilaiseen sanaan kuin lauta $\leftarrow$ 1t. plautas 'saunan laude; mehiläispesän porras', ja Junttila (2015b: 212) ehdottanut, että vi. lõuded lõused 'pääntauti hevosilla' voi olla lainaa samasta balttilaisesta sanasta (lt. liaukos 'kaularauhanen, risa'), johon aiemmin yhdistettiin sm. leuka (mieluummin $\leftarrow$ kba. *kleukā $>$ kro. kljuka 'haka, säppi').

Kksm. ee tai oo on rekonstruoitava sanoihin sm. lieve, nuode, ruoko ja vuota, kksm. ii tai uu sanoihin liika, luuta, niisi, nuutua, siikanen ja viikate. Edellisissä Aikion (2012) määrittelemät vokaalinpitenemisehdot eivät täyty, joten luultavasti yksikään näistä pitkistä vokaaleista ei ole kantasuomalaisen pidentymisen tulos. Supistumalla syntyneitä pitkiä vokaaleita - kuten esimerkiksi uralilaisissa perintö-

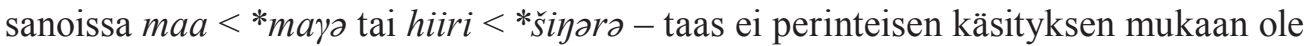
balttilaislainoissa: eräitä löytämiäni supistumadiftongitapauksia esittelen kuitenkin alla. Useimmiten balttilaisen lähtökielen pitkä vokaali on siis substituoitunut suoraan kohdekielen pitkällä vokaalilla. Sama voi periaatteessa koskea myös lähtökielen diftongeja, mutta perinteisesti niitten oletetaan korvautuneen (keski)kantasuomen $V j$ - ja $V w$-yhtymillä, jotka vasta myöhäiskantasuomessa ovat muuttuneet aidoiksi diftongeiksi.

10. Viisi balttilaisetymologiaa on uskottavasti kumottu tutkimuskirjallisuudessa (koipi Nikkilä 2001: 399, laita 'reuna' Wiklund 1911: 232, Junttila 2012: 283, luode Nikkilä 2001: 395-396, nauta Karsten 1915: 137, siipi Junttila 2016b: 469) ja lisäksi neljän sijalle on esitetty parempi etymologia (aika Hyllested 2014: 161-165 $\leftarrow$ germ., laita 'järjestys' Karsten 1937: $183 \leftarrow$ germ., raita 'paju' Koivulehto 2006: 423-426 « germ., vi. tõug 'lajike' Mägiste 1936: 185 = tõug 'sato').

11. Kaikki lähtömuodot ovat kantabaltin sanojen tai sanankantojen summittaisia rekonstruktioita. Useimpien vastineet nykyisissä baltoslaavilaisissa kielissä merkityksineen on mainittu väitöskirjassani (Junttila 2015b). Tässä en käsittele näitä klusiiliedustuksen kannalta enimmäkseen ongelmattomia etymologioita enempää. 


\section{Edustus pitkän vokaaliaineksen jäljessä: geminaattaklusiilitapaukset}

Kaikkiaan soinnitonta balttilaista klusiilia vastaa pitkän vokaaliaineksen jäljessä odotuksenmukainen yksittäisklusiili vain kymmenessä varmassa tapauksessa, sanoissa lauta, leuka, liika, luuta, niisi, nuode, reikä, reisi, seipi ja veikeä. Vastaavanlaista pitkää vokaaliainesta seuraa kuitenkin geminaattaklusiili peräti 22 sanassa, jolle esitettyä balttilaislainaetymologiaa on kannatettu: sm. aitta, haitta, haukkua, juutas, kaikki, kääppä, laukki, laukko, laukku 'aukko', lautta, liete, Liettua, paatti 'hailakka', peikko, peippo, riitta, ruopas, seitti, vaikka ja vaikku 'voima', ka. nautti 'lyhytvartinen kasvi' sekä vs. täüdäs 'tuohiterva'. ${ }^{12}$ Lisäksi on esitetty vielä arvioimattomat etymologiat sanoille sm. paukkua ja vs. kaugas 'tasku'. Yksittäisklusiilisia rinnakkaismuotoja on vain sanoilla peikko ja peippo, joten en tässä erota niitä omaksi luvukseen.

Erillisiä ja alkuperäisiä geminaattasanueita on kuitenkin kolmea vähemmän. Ensinnäkin Thomsenin (BFB 194) erillisinä lainoina esittämät sm. laukki 'valkea läiskä eläimen otsassa' ja laukko 'laukkipää eläin' ovat johdossuhteessa keskenään (vrt. Mägiste 1928: 192, Junttila 2015b: 73-74 ja 190-191). Toiseksi sanat kääppä ja täüdäs voidaan jättää tässä käsittelemättä, sillä niitten pitkä vokaaliaines ei voi olla keskikantasuomalainen. Kääpän pitkä ää on sekundaarin pitenemisen tulosta, sillä balttilaisessa lähtömuodossa on lyhyt vokaali (vrt. artikkelin ensimmäiseen osaan s. 130-133). Eteläviron täüdäs taas on laina esilatvian muodosta degutas, vrt. lv. deguts, 1t. degutas 'tuohiterva' (Nieminen 1959: 201-202), joten sen diftongi on syntynyt vasta $k: n$ heikon asteen kadotessa.

Ensinnä tarkastelen taas onomatopoieettisia sanoja haukkua, peippo ja pauk$k u a$, seuraavaksi suppealevikkisiä $i$-vartaloita paatti, seitti ja nautti sekä vokaalisuhteiltaan ongelmallisia balttilaisetymologioita sanoille ruopas, Liettua ja liete. Paitsi lietteen, myös juuttaan oletetussa lähtömuodossa on soinnillinen klusiili. Balttilaisetymologioissa sanoille haitta ja lautta on toisenlainen ongelmallinen konsonanttisuhde. Niitten jälkeen tarkastelen sanoja laukku, riitta ja vaikku, joille on esitetty vaihtoehtoinen skandinaavinen lainaetymologia, sekä sanoja aitta ja vaikka, jotka on selitetty myös johdoksina. Lopuksi käsittelen uskottavampia balttilaisselityksiä sanoille kaikki, peikko ja laukko sekä viimeisenä äskettäistä balttilaisetymologiaa sanalle kaugas.

sm. haukkua $\leftarrow$ 1t. šaukti 'huutaa; kutsua' (Suhonen 1992: 415-416)

sm. peippo $\sim$ peipponen $\sim$ peiponen $\sim$ peipinen $\leftarrow$ lv. paipala, lt. piepala id.

(Mägiste 1928: 99-100).

sm. paukkaa $\sim$ paukkua $\leftarrow$ lt. baukti 'mylviä'

(Kim 2015: 133-134; ennen arvioimaton etymologia)

12. Lisäksi yhdessä etymologiassa on ehdotettu balttilaisen diftongin lyhenneen geminoituneen klusiilin edellä: kba. *leip $\bar{a}$ 'lehmus' $\rightarrow$ sm. leppä, mutta selitys on epätodennäköinen sekä äännesyistä että merkityseron takia (vrt. Linde 2007: 107-109). 
Liiviä lukuun ottamatta yleisitämerensuomalainen haukkua on käytöltään ja luultavasti myös alkuperältään onomatopoieettinen verbi. Ilmeisesti myös suomalais-karjalainen peippo (muualla itämerensuomessa on saman kuuloisia, mutta muita lintuja merkitseviä nimiä) on useimpien linnunnimien tapaan onomatopoieettinen. Mägiste ja Suhonen ovat esittäneet, että ne voivat siitä huolimatta olla balttilaisia lainoja. Hiljattain on Kim ehdottanut kolmatta näihin rinnastuvaa lainaetymologiaa yleisitämerensuomalaiselle verbille paukkaa $\sim$ paukkua.

Onomatopoieettiset lainat substituoituvat oletettavasti samojen sääntöjen mukaan kuin muukin lainasanasto. Toisaalta kielen fonologian ja fonotaksin muuttuessa uusien äänteitten ja äännerakenteitten leviäminen alkaa tyypillisesti sekä lainoista että ekspressiivisanastosta, joten ei voi pitää mahdottomana, että myös kantasuomen (C)VVCCV-tavurakenne olisi ensinnä tullut käyttöön juuri ekspressiivisissä lainoissa. Vaihtoehtoisena selityksenä on otettava huomioon myöhempi siirtymä muodikkaampaan sanavartaloon ränkyä $\sim$ ronkkua verbin tavoin. Niinpä balttilainen alkuperä on näillä sanoilla mahdollinen selitys, toisin kuin normaalisanaston (C)VVCCV-sanoilla, muttei silti varma, sillä periaatteessa pelkkä äänteellinen motivaatio riittää selittämään minkä tahansa onomatopoieettisen sanan synnyn.

sm. paatti 'hailakka, kellervä' Ł lv. pāts 'kalvakan värinen' (Vaba 1987: 224)

sm. seitti $\leftarrow 1$ l. sietas, saitas 'nuora', lv. saitis, saite 'side, nuora' (SKES)

ka. nautti 'lyhytvartinen kasvi' $\leftarrow$ pr. nauti- 'rääkätä; haaskata; tappaa'

(Kalima 1928: 104-105)

Näitä $i$-vartaloisia sanoja yhdistää suppea levikki. Paatti on SSA:n mukaan kaakkoismurteitten sanastoa Kannakselta Inkeriin, jonne se on lainautunut virosta. Virossa sanan paat : paadi 'haalean värinen' levikki painottuu VMS:n kartan perusteella itään, vaikka esiintymiä sillä on myös saarten ja länsimurteissa. Myös etelävirossa on paat' 'kelmeän keltainen'. Vaba (1987) tukeutuu balttilaisetymologiassaan latvian erilaisia vaalean kalvakoita sävyjä merkitsevän adjektiivin pāts mahdollisiin indoarjalaisiin vastineisiin. Vaikka tämä rinnastus olisikin oikea, ei mikään estä pitämästä sanaa vasta historiallisena aikana latviasta viroon ja sieltä Inkerinmaan kautta suomen murteisiin levinneenä. Samalla tapaa on latvian kielestä suomeen kantautunut myös puusniekka 'lesken kotiinsa naima mies; kotivävy; isäpuoli'. Jos taas lätin sana on lainaa virosta, lähtömuotona voi olla saksan Spat 'sälpä, ei-metallinen mineraali', ovathan maasälvät väriltään jokseenkin vaalean kalvakoita hohkasilikaattimineraaleja.

Seitin ja sen murrevariantit seikki, seikka ja seikkä SSA selittää uskottavasti johdoksiksi sanasta sää 'säie' (tai sen johdoksesta säie; alun perin Pais 1962: 5-6). Diftonginmuodostuksen (ä) äj- > ei- SSA jättää avoimeksi. Tässä sanassa on tuskin enää tapahtunut Suomenlahden kantamurteen äj > ei muutosta (vrt. Kallio 2014: 159), vaan todennäköisemmin vokaalin on vaihtanut kansanetymologinen assosiaatio venäjän sanaan cemb 'verkko'.

KKS:n vain Uhtualta merkitsemä nautti '(huonokasvuisuuttaan) lyhytvartinen kasvi' (joutavie nauttie tuĺi osrašta) on ilmeisesti samaa lähtöä kuin 
etelämpää varsinaiskarjalasta tavattava ńauhti 'hiustupsu, -suortuva; heinätupas; kauna'. Kaliman ehdottamaa balttilaista lähtömuotoa uskottavampi lainaoriginaali löytyy saamesta: psaa. njeavdi 'lampaannata'. Lampaannata on tiheästi mätästävä heinälaji, joka ulkonäöltään muistuttaa heikkokasvuista viljaa.

sm. ruopas 'kiviröykkiö, jääkasa' $\leftarrow$ lv. drupas 'rauniot, jäännökset' (IBL 157)

sm. Liettua $\leftarrow$ 1t. Lietuva id. (Donner 1884: 266)

sm. liete $\leftarrow$ pr. laydis 'savi' (Vaba 1989: 216)

sm. juutas $\leftarrow$ lt. juodas 'musta', lv. jods 'paholainen, paha (metsän)henki' (BFB 175)

Saamelaisperäiseksi on äskettäin osoitettu myös ruopas 'kiviröykkiö, jääkasa' (Aikio 2009: 197). Suomessa sanaa on tavattu vain kannakselaismurteesta, mutta idempänä sen levikki ulottuu aina vepsään saakka, joten saame on luonteva lainanlähde. Lähtömuoto tavataan merkityksessä 'kivikasa' kiltinästä ( $\left.r u \jmath^{\prime} b b\right)$ ja turjasta (rié $b b e$ ). Kuten Metsmägi (2015) esittää, kokonaan toinen sana on vi. roobas rööbas 'kärrynpyörän ura tiessä; raide', jonka lähtömuoto on kas. grope 'ränni'. Mitään yhteyttä ei Kaliman tavoin tarvitse olettaa lätin sanaan drupas 'rauniot, jäännökset', jonka ensi tavun vokaali ei vastaa oletettua lainasanaa: ba. $u$ :n tulisi edustua ims. $u$ :na.

Myös Liettuan ja lietteen balttilaisetymologiat ovat vokaalisuhteiltaan ongelmallisia. Ehdotettujen lähtömuotojen 1t. ie ja pr. ai \{ay\} palautuvat kantabaltin $i$-loppuisiin diftongeihin, jotka eivät vanhoissa balttilaislainoissa milloinkaan edustu ksm. ee:nä. Liettuan kohdalla tästä on huomauttanut jo Thomsen (1890: 103) lisäten, että alueen nimi tuskin on voinut säilyä kielissä, joitten suora yhteys siihen on katkennut jo puolitoista tuhatta vuotta sitten - eikä siitäkään ole mitään takeita, että kantasuomen balttilaista kontaktikieltä puhunut väestö edes käytti tätä nimeä. Thomsen selittää Liettuan viron vastineineen (gen. Leedu) uskottavasti lainoina venäjästä.

Lietteen väitetyssä balttilaisessa lähtömuodossa on vieläpä soinnillinen klusiili. Liete onkin johdos yleisitämerensuomalaisesta verbistä liettää 'erottaa huuhtomalla; kuljettaa lietettä', jonka alkuperä on tuntematon (vrt. SSA). Merkitykseltään sopiva originaali olisi germaaninen 'virrata'-verbi, kgerm. *fleutan > ru. flyta jne., mutta ainoa siihen kuuluva ensi tavun vokaalin puolesta sopiva lähtömuoto olisi kas. vleten. Alasaksilainen laina tuskin kuitenkaan olisi levinnyt koko itämerensuomeen. Kenties kantasuomessa on vanhasta perintösanasta *leemi (> sm. liemi) hahmotettu (takaperojohdettu) verbivartalo *lee-, josta sitten on johdettu kausatiivi *lee-ttä-? ${ }^{13}$

Soinnillisen klusiilin edustus on ongelma myös sanan juutas balttilaisetymologiassa. Juuttaan ja sen viron vastineen juudas balttilaisperäisyyttä on viimeksi

13. Artikkelin vertaisarvioija on ehdottanut vastaavan takaperojohdoksen lähtömuodoksi adjektiivia lievä 'löyhä, löyhään kierretty lanka'. Sen yhteyteen sopii hyvin verbi liestyä 'purkautua (lanka)' (vrt. SSA) ja merkitys 'löyhä' yhdistää kumpaakin myös yleisitämerensuomalaiseen liettää-verbiin. Merkityssyistä eri alkuperää on lievä 'mieto, heikko, vähäinen', vi. leeb, leev 'lauha', joka liittyy adjektiiviin liepeä ja on ehkä germaaninen laina (LägLoS s.v. lievä). Sanojen lievä 'löyhä' ja liestyä levikki ei kuitenkaan ulotu Suomenlahden eteläpuolelle, joten liettää on tuskin johdettu niistä. 
puolustanut Breidaks (1983: 48), jonka mielestä osa sanan merkityksistä voidaan erottaa raamatullisesta nimestä Juudas ja liittää etymologialtaan tuntemattomaan balttilaiseen *jōda-sanueeseen. Lt. juodas merkitsee vain 'mustaa', mutta lv. jods 'paholaista' ja 'pahaa henkeä', joihin Breidaks palauttaa suomen ja viron sanojen merkitykset. Vain 'kavaltajan' ja 'juutalaisen' merkitykset Breidaks johtaa Juudas Iskariotin nimestä. Merkitysten erottamiseen ei kuitenkaan ole mitään syytä, kuten jo Mägiste (1927: 70, 1932: 138-139) on vakuuttavasti osoittanut. Pikemminkin on ajateltava myös lätin jods-substantiivin nykymerkityksen syntyneen kristillisen tradition vaikutuksesta.

sm. lautta $\leftarrow$ 1t. plaustas id. (Klimavičius 1977: 108)

sm. haitta $\leftarrow$ 1t. žaizda 'haava' (Orrman 1993: 99-100)

Balttilaisetymologiat sanoille lautta ja haitta edellyttävät hyvin varhaisia lähtöasuja, joissa laajalevikkinen indoeurooppalainen äänteenmuutos $T+T>S T$ ei olisi vielä ehtinyt tapahtua. Tällaiset asut ovat tuskin mahdollisia kantasuomen balttilaislainoissa, joissa lähtökielen $-s t-n$ ja $-z d$-n säännöllinen edustus on -st-, eivätkä ne ainakaan ole yhdistettävissä tavurakenteeltaan myöhäisiin itämerensuomalaisiin muotoihin (Junttila 2015b: 183). Pohjoisen itämerensuomen lautalle onkin esittänyt ongelmattoman germaanisen (skandinaavisen) etymologian jo Thomsen (GSI 129). Haittaa taas ei ole aiemmin selitetty etymologisesti. Sen levikki kattaa suomen, karjalan ja Kukkusin vatjan. Sanalla on konkreettinen merkitys 'lukon salpa, avaimen pidäke', joka ei lainkaan sovi Orrmanin balttilaislainaoletukseen. Luultavasti haitta onkin yhdistettävä ruotsin sanaan hejd 'övre gräns, måtta', murt. häjd 'stängsel' < ksk. *hagipo, joka on johdos verbistä *hagjan 'förse med stängsel, inhägna' (SEO s.v. hejd, EDPG s.v. *haga(n)-). Laina kuuluu siis pohjoiskantasuomen kantaskandinaaviseen kerrostumaan.

sm. laukku 'aukko', vi. laugas 'suonsilmäke' Ł lt. laukas 'pelto, aukea ym.' (Saareste 1922: 144)

sm. riitta 'pino' $\leftarrow$ ba. *reita, vrt. lt. rieti 'pinota' (Liukkonen 1999: 121-122)

sm. vaikku 'voima' $\leftarrow$ 1t. viekas 'voima; aika' veikus 'reipas' (Toivonen 1931)

Nämäkin sanat selittyvät parhaiten varhaisina skandinaavisina lainoina. Jo Koivulehto (1971a: 20-23) on löytänyt germaanisen alkuperän suomen sanalle laukku '(veräjän) aukko; notkelma; savikuoppa', jonka kanssa samaa lähtöä on myös viron laugas 'suonsilmäke, aukko, lammikko'. Kuten LägLoS esittää, germaaninen lähtömuoto *lauk-> sa. Lauch 'sola, aukko kallionseinämässä; kansi' on semanttisesti lähempänä suomen ja viron sanoja kuin Mägisten originaaliksi olettama lt. laukas.

Sanan riitta 'pino (olkia, heiniä, lautoja)' esittää SSA lainana ruotsin murteellisesta verbistä rīt(a) 'pystyttää, nostaa pystyyn; ojentaa; suunnata'. LägLoS vastustaa SSA:n selitystä, koska ruotsin verbiltä puuttuu sopiva nominikorrelaatti, ja pitää parempana Liukkosen rinnastusta liettuan verbiin rieti 'pinota'. Lainan lähtömuodoksi 
sopivaa nominikorrelaattia ei kuitenkaan ole liettuankaan verbillä. Riitan levikki on laaja, mutta sopii silti lainautumiseen lännestä: sana tavataan koko eteläisen itämerensuomen lisäksi suomen hämäläis- ja eteläpohjalaismurteista ja näitten lähiympäristöstä (SSA). LägLoS hyväksyy skandinaavisen laina-alkuperän riimisanalle piitta, jolla on samankaltainen levikki: se ulottuu etelässä liiviin, muttei idässä suomen länsimurteitten taa. Viikinkiajan skandinaaviset lainat ovat luonnollisesti voineet levitä itämerensuomen länsiosassa yhtä laajalti kuin saman aikakauden slaavilaisperäinen kristillinen terminologia, joka on jo kauan tiedetty yleisitämerensuomalaiseksi (vrt. Schalin 2018: 147-148).

Suomen pohjoisten murteitten vaikku $\sim$ vaikko on Rytkösen (1937) mukaan erityisen tavallinen sanonnassa vaikkua kynnen alla 'voimaa', erityisesti lasten ja vanhusten suhteelliseen voimakkuuteen viittaamassa. Toivonen (1931) on liittänyt sen liettuan sanoihin viekas '(elin)voima; (elin)aika', veikti 'toimia; saada aikaan; vaikuttaa' ja veikus 'nopea; kiireellinen; reipas' sekä lätin verbiin veikt 'toteuttaa, suorittaa'. Semanttista ongelmaa ei balttilaisetymologiassa ole, mutta sanan suppea levikki ajaa hakemaan sen alkuperää muualta. Rytkönen ehdottaa lainaa muinaisskandinaavista, lähinnä sanoista kveik 'liha kynnen alla' ja kveika 'sytyke', jotka kummatkin kuuluvat johdoksina kantagermaanin adjektiivin *kwiwa- * *wikwa- 'elävä, eloisa' yhteyteen. Samaa alkuperää olisi näin myös laajalevikkinen (sm. ink. ka. va. vi. vs.) vaikku, joka Suomenlahden pohjoispuolella merkitsee 'korvavahaa' ja eteläpuolella (va. vaikko, vi. vs. vaik) 'pihkaa'.

Rytkösen esittämä skandinaavinen sanue sopii hyvin vaikun lainaoriginaaliksi, vaikka LägLoS epäilee etymologiaa sillä perusteella, että lähtömuodoksi sopiva substantiivi näyttää puuttuvan. Itse asiassa todennäköinen lähtömuoto on Rytkösen mainitsemien joukossa, mutta hän ei onnistunut rekonstruoimaan sanan itämerensuomalaisia merkityksenkehityksiä. Rytkönen oletti abstraktioitten konkreettistumisia 'puun elo' > 'pihka' sekä 'voima' > 'parantavaa voimaa sisältäväksi uskottu aine' > 'korvavaikku', mutta ne olisivat korkeintaan voineet tapahtua tabua kierrettäessä. Luultavasti kuitenkin kantaskandinaavin 'sytykettä' merkitsevä *kwaikō (> msk. kveika) on lainautunut merkityksessä 'pihka', josta muut merkitykset ovat kehittyneet myöhemmin. Pihka sopii erinomaisesti sytykkeitten valmistamiseen. Vaikku 'korvavahan' merkityksessä lienee syntynyt ensin yhdyssanana, jota edelleen vastaa viron kõrvavaik id., ja määriteosa on jäänyt pois vasta vaikun lakattua merkitsemästä pihkaa. Myös merkitys 'voima, tarmo' on voinut metaforisesti kehittyä 'pihkaa' merkitsevälle sanalle (vrt. tervaskanto merkityksessä 'terve, voimakas vanhus'), mutta taustalla voi lisäksi olla siihen lainautuessa assosioitunut msk. veig 'voimajuoma; voima' tai pikemminkin sen jatkaja myöhemmissä ruotsin murteissa. Idiomi vaikkua kynnen alla saattaa sisältää samanlaisen kansanetymologisen tulkintalainan sanasta msk. kveik 'liha kynnen alla'.

Vaikun yhteyteen kuuluu levikiltään suomalais-karjalainen vaikuttaa monine murremerkityksineen: 'olla vaikutusta, tehota, tepsiä (laajalti murt.); tuntua jltak; toimia, esiintyä jnak (paik. murt.), kannattaa, hyödyttää (Pohjois-Suomi); jankuttaa, kärttää, muistuttaa (paik. murt.)'. Jos verbin varhaisimpia merkityksiä suomessa ovat 
Rytkösen mainitsemat 'pyytää, vaivata; houkutella; särkeä, tehdä kipeätä', saattaa lähtökohtana olla sama konkreettinen merkitys kuin aivan samoista aineksista koostuvalla viron verbillä vaigutama 'ajaa/valuttaa männystä pihkaa'. Tässä suhteessa valaisevia ovat Rytkösen esimerkit vaikuttaa joku pahuuteen, vaikuttaa kala pyyntiin ('pyydykseen'), haava vaikuttaa sekä Torniosta poimittu lause Se [kerjäläinen] vaikutti niin kauan aikaa, en mie päässy siitä erinhänsä ennen kun annoin. Merkitysten 'tehota, olla vaikutusta' pohjalla voi olla myös viron vaigutama-verbin toinen perusmerkitys 'pihkata, suojakäsitellä (esim. vene) pihkaa sisältävällä aineella'.

sm. aitta $\leftarrow$ kba. *aitā, vrt. lt. ait(i)varas 'painajainen, lentävä kummitus; kratti', slov. po|jata 'aitta' (Lidén 1911: 198-202)

sm. vaikka $\leftarrow$ lt. viekas 'voima; aika' (Koivulehto 1989: 188)

Yleisitämerensuomalainen aitta on ajaa-verbin johdos. Mägiste (1977: 157-157) on esittänyt johdossuhdetta aitta ja aittua 'turvota, paisua' $\Leftarrow$ ajo $\Leftarrow$ ajaa (vrt. navetta $\sim$ nauta, ometta oma), mutta ajo ei äänneasultaan sovi välikantasanaksi. Aittua on refleksiivis-passiivinen johdos $<* a j e-t t u-$, jossa $*_{-} e$ - liittyy passiivin tunnukseen. ${ }^{14}$ Myös aitta $<*$ aje-tta selittyy suoraan ajaa-verbistä johdetuksi, sillä siihen rekonstruoitava $-e$ - on sama kuin johtosuhteissa navetta $\Leftarrow$ nauta ja ometta $\Leftarrow$ oma. Mägisten semanttiset argumentit etymologiansa tueksi riittävät. Aittaan verratuilla slaavilaisilla sanoilla ei ole varmaa etymologiaa eikä lt. aitvaras välttämättä liity niihin mitenkään (vrt. SEJL).

Johdoksena selittyy myös konjunktio vaikka, murt. vaihka, joka tavataan vain suomesta, inkeroisesta ja karjalasta. Hakulinen (1948) on selittänyt sen myöhäiskantasuomen substantiivin *vajeh ( $>$ sm. vaihe) ja liitepartikkelin $k a$ yhteensulaumana. Ensi tavun diftongi on siis samanlaisen *aje $>$ ai-supistuman tulos kuin aitta-sanassa.

sm. kaikki $\leftarrow$ lt. kiek, lv. cik 'kuinka paljon; mitä tahansa; jokainen' (BFB 186)

Liiviä vaille yleisitämerensuomalainen kaikki on ainakin kahdessa mielessä ainutlaatuinen. Se on $e$-vartaloisista nomineista ainoa, jonka ensimmäinen tavu on rekonstruoitava ylipitkäksi jo myöhäiskantasuomeen: sen pitkä vokaaliaines ei siis ole myöhäisen pitenemisen tulosta niin kuin esimerkiksi sanassa kiiski. Lisäksi sanassa on erikoinen diftongisuhde sm.-ve. $a i \sim$ va.--vi. $\tilde{o} i \sim$ vs. $y i, y$.

Thomsenista alkaen kvanttoripronominia kaikki on enemmän tai vähemmän epäröiden pidetty lainana balttilaisesta sanasta, jota vastaavat lt. kiek(a) ja lv. cik 'kuinka paljon; mitä tahansa; jonkin verran; kuinka paljon tahansa; jokainen'. Ostrowski (2014) on hiljattain ehdottanut, että näitten balttilaisten muotojen takana on *kajaka, neutrimuoto pronominista kajakas 'kuka, mikä tahansa', joka sellaisenaan esiintyy liettuan sanakirjassa vuodelta 1642. Ostrowskin mukaan kajakas on muodostunut kysymyspronominin kas 'kuka, mikä' liittyessä relatiivipronominiin kaja,

14. Kiitos tästä huomiosta kuuluu artikkelin vertaisarvioijalle. 
joka puolestaan on syntynyt pronomininvartaloitten $k a$ - ja ja- yhtymästä. Näyttää siis ilmeiseltä, että itämerensuomen sanojen lähtömuoto on ollut jokin kolmitavuinen *kajakas-pronomininin muoto, luultavasti monikollinen *kajakei 'ketkä, mitkä tahansa'. Keskikantasuomeen se on lainautunut muodossa *kajekki, josta supistuman -aje->-ai- tuloksena > *kaikki (vrt. yllä aitta, vaikka; päätelmäluvussa esittelen lisää supistumatapauksia). Tämäkään sana ei siis ole lainautunut CVVCCV-muotoisena, vaan on myöhemmin supistunut sellaiseksi.

sm. peikko $\leftarrow$ lt. paikas 'tyhmä, uppiniskainen' (Ritter 1977: 173)

sm. laukki, laukko $\leftarrow$ lt. laukis, laukas 'vaalea täplä eläimen otsassa'

(Donner 1884: 268)

Suomen sanaa peikko on viimeksi käsitellyt Koivulehto (2005). Hän selittää sen oijohdoksena balttilaisperäisestä lainavartalosta, jonka lähtömuotona on (kanta)baltin *peika-. Liettuassa sitä vastaa paikas 'tyhmä, uppiniskainen', jota jo Ritter on esittänyt peikon originaaliksi. Semanttisesti etymologia on moitteeton, sillä useat samakantaiset balttilaiset ja indoeurooppalaiset sanat merkitsevät myös 'pahaa, ilkeätä olentoa' ja 'paholaista'. Johdinainesta on peikossa kuitenkin myös geminaattaklusiili: morfologisen uudelleenhahmottamisen kautta se on siis muuntunut pohjoisessa itämerensuomessa $-k k o(i)$-päätteiseksi: vrt. veikko $(\Leftarrow v e i j o) \Leftarrow v e l i$. Suomen lounaismurteitten peiko(i) selittyy heikkona asteena $i$-päätteisten diftongien edellä, mutta virossa on säilynyt yksittäisklusiilinen peig : peiu 'sulhanen', jonka poikkeavan merkityksen Koivulehto onnistuu myös selittämään 'naisenryöstäjän' välimerkityksen kautta. Toisella samaan semanttiseen ryhmään kuuluvalla balttilaislainalla kouko 'aave; suurpeto; täi' vi. kõu 'ukkonen' on päinvastoin viron murteissa *-kkoi-päätteinen rinnakkaismuoto kõuk: kõugu.

Yleisitämerensuomalainen laukko(i) laukki laukas $\sim$ laukka merkitsee joko vaaleata läiskää eläimen otsassa tai pars pro toto eläintä, jolla tällainen läiskä on. Aivan samat merkitykset on liettuan sanoilla laukas (= lv. lauks $<*$ lauka-) ja laukis $(<*$ laukja-), joten Donnerin esittämä etymologinen yhteys on ilmeinen. Muotojen yhdennäköisyys toista tavua myöten on kuitenkin näennäistä, sillä kaikista itämerensuomen muodoista voidaan erottaa jokin yleinen geminaatta-k:llinen suffiksi: *-kkoi (vrt. peikko yllä!), *-kki, *-kkAs tai *-kkA. Ne ovatkin johdoksia samasta *lauka-kannasta kuin sm. laukama, jolle SSA antaa merkitykset 'aukkopaikka pellossa, niitetty ala; karvaton ala eläimessä; mustelma; suvantopaikka koskessa'. Tällainen geminaatallisten suffiksien sulauminen *lauka-kantaan on samantapainen suffiksinvaihtoilmiö kuin geminaatallisen peikko-muodon synty. Suffiksinvaihdon on luultavasti laukaissut sekundaari assosioituminen merkitykseltään yleisluontoisempaan germaanisperäiseen (vrt. LägLoS), tavurakenteeltaan nuorempaan (ksk.?) laikka laikku 'täplä' -sanueeseen. Liivissä tämä on johtanut kahden erilähtöisen sanan täydelliseen samastumiseen (laik 'laukkipää eläin, täplä eläimen otsassa').

Laukama merkityksessä 'aukkopaikka pellossa, niitetty ala' ja SSA:n samassa yhteydessä mainitsemat sm. laukku, -pää 'aukkopaikka pellossa t. metsässä', ve. 
loukuz 'pellon t. niityn osa' ja vi. laugas 'paljas kohta viljapellossa' ovat saman balttilaisperäisen *lauka-kannan johdoksia. Viimeksi mainittujen äännerakenteeseen on puolestaan voinut vaikuttaa yllä mainittu germaanisperäinen sanue sm. laukku 'aukko, reikä, et. veräjänaukko; notkelma, savikuoppa', vi. laugas lauk (: laugu) 'suonsilmäke, aukko, lammikko'. Lt. laukas ja lv. lauks merkitsevät myös avointa, metsätöntä maata, peltoa, maaseutua ja aukiota. Kaikkia sanan merkityksiä yhdistää vaaleus tai valoisuus, ja se palautuukin indoeurooppalaiseen juureen *leuk- 'leuchten, Licht' (LEW; vrt. myös Uotila 1970: 3-10). Kolmas laukaman päämerkitys 'suvantopaikka' taas liittyy laukea-sanueeseen (mm. sm. lauka 'tyyni meri', vi. lauge 'loiva, tasainen', li. lougy 'hidas; hiljainen'), jonka yhteys balttilaiseen lauka-kantaan on merkityssyistä hyvin epävarma.

vi. vs. kaugas 'tasku' $\leftarrow$ ba. *kauk-, vrt. 1t. kaukas 'puukenkä', kauke 'naamio, maski; kippo, nappo' (Vaba 2014: 222-226; ennen arvioimaton etymologia)

Kaugas 'tasku' on erityisen tavallinen Mulkin murteessa, mutta VMS:ssa siitä on tietoja laajemmaltikin, myös pohjoisviron puolelta. Vaba liittää sen balttilaiseen *kauksanueeseen, johon kuuluvia sanoja käsittelin ensimmäisessä osassa itämerensuomalaisen $k u k k a \sim k u k k u$ sanueen yhteydessä. Tässä tulevat kyseeseen lähinnä $o$-asteiset muodot, joissa on kantabaltissa diftongi au. Balttilaisen sanueen 'paisumiseen' ja 'pullistumiseen' liittyvään semantiikkaan 'tasku' sopii verraten hyvin, mutta merkitykseen ja äänneasuun sopivaa yksittäistä balttilaista lähtömuotoa ei ole löydetty. Fraenkelin (LEW) mukaan samaan sanueeseen kuuluvat myös lt. kaukas 'kääpiömäinen haltija, tonttu' ja pr. cawx 'piru', joita vastaavasta kantabaltin *kauka-sanasta on lainautunut sm. kouko 'aave; suurpeto; täi', vi. kõu 'ukkonen'. Jo viron äänneasujen kaugas ja kõu vertaaminen antaa osviittaa näitten lainojen välisestä ikäerosta. Koska levikkikin on kaugas-sanalla suhteellisen suppea ja painottuu kielialueen etelälaidalle, sen lähtömuotoa tulisi mieluiten etsiä latviasta tai muinaislatgalista. Samaan lainakerrostumaan kuulunee levikiltään yhtä lailla suppea vs. kuvvas 'kirveenvarsi' $<* k u u d a s \leftarrow$ esilatgalin *kōdas (vrt. Nieminen 1959: 202-204).

\section{Päätelmät}

Kaikista 42 käsittelemästäni pitkän tavuaineksen jälkeisen geminaattaklusiilin sisältämästä balttilaisetymologiasta olen hylännyt 30. Hylkäämistäni etymologioista puolet (sm. aitta, karppa, karppi, karttu, kärppä, laukku, liete, Liettua, lorppi, porkkana, ruopas, seitti, vi. kärpima, vs. mulk' ja virp') oli jo kannatuksensa menettäneitä, mutta yksi (vi. erk) oli vielä arvioimaton, 12 (sm. haitta, juutas, kartta, lautta, paatti, pirtti, riitta, vaikka, vaikku, ka nautti, li. keŗk $\sim$ vs. kirges $\sim$ vs. käokirg' ja vs. mülgas) kiistanalaisia ja kaksi (sm. kurpponen ja varttua) peräti yleisesti hyväksyttyjä. Ilmeni myös, etteivät li. kerk, vs. kirges ja vs. käokirg' kuulu samaan sanueeseen, vaan kaikilla kolmella on eri alkuperä. 
Täysin vaille uskottavaa alkuperänselitystä jäävät vielä suomen karttu, kärppä ja mulkku ( vs. mülgas). Muille 29 sanalle on esitetty vähintään todennäköinen etymologia. Näistä 11 on tämän artikkelin uusia etymologioita ja neljä parannettuja versioita vanhoista.

Kantaskandinaavinen laina on (1) sm. haitta $\leftarrow$ ksk. *hagipō (> ru. hejd 'övre gräns, måtta', murt. häjd 'stängsel'). Muinaisitäslaavilaisina lainoina olen selittänyt kaksi sanaa: (2) sm. karppa 'lumenkuori, routainen maa; noki' (= vi. karp 'puun kuori; likakerros; känsä, rupi') $\leftarrow$ mven. *скоруna, ellei (Vilkuna 1965) $\leftarrow$ sk.; (3) sm. kurpponen 'tietynlainen kenkä; huono, ryppyinen tms. esine', kurppu 'ryppy, poimu' joko $\leftarrow$ ven. murt. kúrpy, kurpíny 'hamppunuorasta tehdyt kengät' ( $\leftarrow$ ba.) t. $\leftarrow$ mven. * ${ }^{*}$ zрn- $=$ srb-kro. krplje 'vanhat kengät', pl. kierpce 'virsujen tapaiset jalkineet'; Latvialaista alkuperää lienee (4) vs. virp' 'vyyhteämisvirhe; harhakuva' $\leftarrow 1$ v. virp- > virpa 'pyörre', virpties 'kieppua; huimata', virpināt 'pyörittää, rullata; värisyttää', mahdollisesti myös (5) sm. paatti 'hailakka, kellervä' $\leftarrow$ vi. paat id. $\leftarrow$ lv. pāts 'kalvakka'. Jälkimmäinen on kuitenkin voinut lainautua virosta latviaan, jos sen lähtömuotona onkin saksan Spat 'sälpä'. Saksalaista tai alasaksilaista alkuperää olen ehdottanut kahdelle muullekin sanalle: (6) sm. ka. porkkana, vi. porgand, li. borkyn, vs. põrk'nas, põrg'nas saBa. Borkane, Burkane, ven. murt. бурка́н, борка́н, барка́н, lv. burkāns id. ( 1t. burkantas 'palsternakka', Burkantas $) \leftarrow$ kas., vrt. sa. Burgund, holl. Bourgondië 'Burgundi' (jo Junttila 2014); (7) va. karppi, vi. karp ( $\rightarrow$ sm. karppi), vs. karp', li. kaŗp kärp 'puinen laatikko, rasia ym.' $\leftarrow$ saBa. Karp $\sim$ Karpe t. kas. karpe id. (joko suoraan tai latvian välityksellä $\leftarrow$ mven.). Saamesta on lainattu (8) ka. nautti 'lyhytvartinen kasvi' $\leftarrow$ psaa. njeavdi 'lampaannata'. (9) Verbille liettää olen ehdottanut hypoteettista alkuperää morfologisen uudelleenhahmottamisen kautta sanasta liemi syntyneenä johdoksena. Kontaminaatioina olen selittänyt kaksi sanaa: (10) li. keŗk, Sal. ķirik 'kotisirkka; kilkki' < mksm. *kirkki sanojen sirkka ja kilkki kontaminaationa, sekä (11) vs. käo|kirg' 'leppäkerttu' sanojen käo|kiräs id. ja kirg' 'kipinä' kontaminaationa. ${ }^{15}$

Yhteen skandinaaviseen ja yhteen alasaksilaiseen lainaetymologiaan sekä kolmeen johdosselitykseen olen ehdottanut täsmennyksiä: (1) sm. murt. vaikku 'voima' < 'pihka' + merkitysvaikutus sanoista msk. veig 'voimajuoma; voima' ja kveik 'liha kynnen alla'; sm. ink. ka. vaikku 'korvavaha', va. vaikko, vi. vs. vaik 'pihka' $\leftarrow$ ksk. *kwaikō > msk. kveika 'sytyke'; (2) vi. kärpima 'karsia, typistää, leikata; teroittaa'

15. Lisäksi olen esittänyt artikkelin varsinaisen pääaineiston ulkopuolelta lainaetymologiat sanoille (1) sm. ka. kirki, vi. kirg 'kiima, lemmenkiihko; himo, halu', vs. kirg 'kipinä; liekki', li. ķireg 'kipinä' $\leftarrow$ kba. *gir-k- (> lv. dzirksts, dzirkstele 'kipinä') ja (2) ink. kurttaa, va. kurtta, vi. kurtma, kurtama, kurtuma ym. 'valittaa; riutua, surkastua' $\leftarrow$ msl. * ${ }^{*}$ zpm- $>$ ven. кopmems 'tuntea kipua; toivoa hartaasti', murt. kurtat' 'sairastaa, olla sairaalloinen', srb-kro. krtav 'kuihtunut, surkastunut, näivettynyt'.

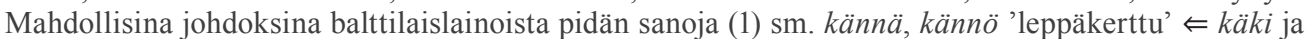
(2) sm. murt. malkaista 'laimentaa, ohentaa, heikentää (makua tai vaikutusta); vähentää ruokahalua; viilentää; leudontaa; auttaa, tulla neuvoksi' $\Leftarrow *$ malkka 'ohut' $(\sim$ malka $)$. Skandinaavisesta lainasta on johdettu (3) sm. ka. vaikuttaa < 'pyytää, vaivata; houkutella; särkeä, tehdä kipeätä' < 'ajaa/valuttaa männystä pihkaa' $\Leftarrow$ vaikku 'pihka'. Itämerensuomalaisen kielialueen sisäistä lainautumista olen ehdottanut sanassa sm. kuuro, ka. kuurnis $\longleftarrow$ ly. kuurniz $\sim$ kuurniš ( $\longleftarrow$ ba.). 
sm. murt. kärppiä 'karsia', kärppi 'terävä' $\leftarrow$ kas. scherpen 'teroittaa' (t. sk. *skerpa) + merkitysvaikutus verbistä kas. kerven 'karsia, typistää, leikata'; (3) sm. aitta (ka. ly. ve. va. vi. li. vs.) $<* a j e-t t a \Leftarrow$ ajaa ja aittua 'turvota, paisua' $<* a j e-t t u$ - $\Leftarrow$ ajaa;

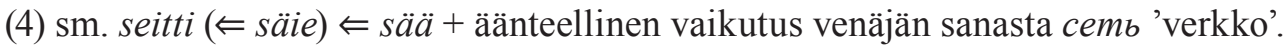

Neljäntoista sanan (sm. juutas, kartta, laukku, lautta, Liettua, lorppi, pirtti, riitta, ruopas, vaikka, varttua, vi. erk, vs. kirges ja mulk' etymologiat ovat aiemmin tunnettuja ja kannatettuja. Kolmen tueksi olen esittänyt uusia argumentteja: (1) sm. ka. kartta 'kaukalo' $\leftarrow$ mven. корыто; (2) sm. riitta 'pino' $\leftarrow$ ru. murt. rït(a) 'pystyttää; ojentaa; suunnata'; (3) vs. kirges $\sim$ kirges' $\sim$ kirgets' $\sim$ kirgats' $\leftarrow$ ven. murt. киргиз 'kirgiisi, kazakki; torakka'.

Muista kahdestatoista balttilaisperäisenä pidetystä sanasta viisi on joko selvästi onomatopoieettisia (haukkua, paukkua ja ronkkua) tai ainakin luultavasti onomatopoieettista lähtöä (harakka ja peippo). Tällaisten sanojen esihistoriasta voidaan tuskin koskaan sanoa mitään varmaa. Niitten balttilaista lainaetymologiaa puoltaa kaksi argumenttia, jotka liittyvät ikonisille sanoille tyypilliseen ekspressiivisyyteen. Yhtäältä pitkän tavuaineksen jälkeiset geminaatat ovat varmaankin yleistyneet kantasuomessa merkitykseltään ekspressiivisistä lainoista alkaen, ja tämä kehitys on saattanut alkaa jo balttilaiskontaktien kauden aikana. Toisaalta juuri ekspressiivisanat ovat hyvin alttiita morfologiselle uudelleenhahmottumiselle ja siitä johtuville suffiksinvaihtoilmiöille (vrt. Koski 1986).

Eteläisen itämerensuomen suppealevikkiset sanat vs. Leivu ärk' 'puutiainen' ( 1t. erké, lv. érce 'punkki') ja vi. vs. kaugas 'tasku' ( $\leftarrow$ ba. *kauk- 'paisua, pullistua') ovat suhteellisen varmasti balttilaisperäisiä, mutta kantasuomea myöhempiä. Niitten äännepiirteet ja levikki tukevat osaltaan oletusta erillisestä muinaislatgalilaisesta lainakerrostumasta etelävirossa (Junttila 2016b).

Jäljelle jää viisi uskottavaa vanhaa balttilaislainaa. Yksi jatkaa sellaisenaan kantasuomeen lainattua balttilaista sanaa: (1) sm. (ka. ly. ve. va. vi. vs.) kaikki $<\mathrm{ksm}$. *kajekki $\leftarrow$ kba. mon. *kajakei vlt. kajakas 'kuka, mikä tahansa', *kajaka > lt. kiek, lv. cik 'kuinka paljon; mitä tahansa; jokainen'. Neljän muun lainan johdokset ovat syrjäyttäneet sijaltansa alkuperäisen lainavartalon joko osassa itämerensuomea tai koko levikkialueella: (2) sm. laukki, laukko 'vaalea täplä eläimen otsassa' < *lau-kkoi $\Leftarrow \mathrm{ksm}$. *lauka- + äännevaikutus sanalta laikka, laikku ( $\leftarrow$ sk.); sm. laukama, laukku 'aukkopaikka pellossa t. metsässä', ve. loukuz 'pellon t. niityn osa', vi. laugas 'paljas kohta viljapellossa' $\Leftarrow \mathrm{ksm}$. *lauka $\leftarrow$ ba. *lauka- > lt. laukas 'vaalea täplä eläimen otsassa; avoin, metsätön maa; pelto; maaseutu; aukio'; (3) sm. peikko <* pei-kkoi $\Leftarrow$ *peikoi vi. peig 'sulhanen' Ł ba. *paikas 'ilkeä olento, paholainen' > 1t. paikas 'tyhmä, uppiniskainen'; (4) vi. vs. malk, li. mālka 'painopuu, salko, kalikka, riuku ym.' $<*$ mal-kka 'ohut (salko)' $\Leftarrow$ sm. malka $\leftarrow$ ba. $*($ s)malka- $>$ lv. smalks 'hieno, ohut'; (5) vi. kurt, vs. kurt' 'kuuro' $\Leftarrow *$ *kurte- ( ve. kurdiž, va. kurre id.) + äänteellinen vaikutus verbistä *kurtta- 'valittaa; kärsiä; surkastua, näivettyä'; ksm. *kurteh *kurtes 'kuuro' Ł ba. *kurt(i)as.

Ensi tavun diftongi sanoissa kaikki, aitta ja vaikka on osoittautunut supistuman eli kahden tavun yhteensulautumisen tulokseksi: ne palautuvat keskikantasuomalaisiin 
muotoihin *kajekki, *ajetta ja *vajehka. Tällainen supistuma-ai näyttää olevan itämerensuomessa yleisempi kuin aiemmin on ajateltu: äskettäin on Hyllested (2014: 161-165) löytänyt sellaisen sanasta aika $(<\mathrm{kksm}$. *ajeka $\leftarrow$ kgerm. *ajuka) ja vielä yksi on balttilaislainassa aisa, jonka lähtömuodoksi tulee slaavilaisten kielten (slov. oje, mon. ojesa 'aisa' ym.) pohjalta rekonstruoida kantabalttiin kolmitavuinen neutri *ajesa (vrt. Junttila 2016c: 218-219), eikä kaksitavuinen aisa-, niin kuin aiemmin on esitetty. Sanan haitta diftongi ei ole näin vanha, vaan syntynyt vasta $k$ :n heikon asteen kadotessa muodosta *hayitta $\leftarrow$ ksk. *hagipō.

Useista tässä käsittelemistäni sanueista näkyy alkuperältään erilähtöisten sanojen vaikutus toistensa äänneasuun tai merkitykseen. Vaikutuslähde kuuluu usein saman kielen leksikkoon kuin vaikutuksen kohde, mutta se voi olla myös minkä tahansa kontaktikielen sana. Välttämätön ehto vaikutukselle näyttää olevan vain sekä muodon että merkityksen jonkinasteinen samankaltaisuus vaikutuslähteen ja -kohteen välillä. Usein tällainen vaikutus voidaan Kosken (1986) tavoin määritellä morfologisen uudelleenhahmotuksen kautta tapahtuvaksi suffiksinvaihdoksi: esimerkiksi viron ja eteläviron esimuotojen *kurtti 'kuuro' on voinut syntynyt juuri näin, jos verbi *kurtta- 'surkastua, näivettyä' on mielletty aiemman *kurte-vartalon johdokseksi ja tämän seurauksena on verbistä muodostettu $i$-johdos, joka sitten jostain syystä on torjunut tieltänsä aiemman muodon *kurre $(h)(<* k u r d e h<* k u r t e \check{s})$ 'kuuro'.

Monissa tapauksissa on vaikutus kuitenkin pelkästään semanttinen: näin kas. kerven 'karsia, typistää, leikata' on lisännyt oman merkityksensä viron verbille kärpima 'teroittaa' muuttamatta sen muotoa; samoin on varmaankin msk. veig 'voimajuoma; voima' antanut aiemmin 'pihkaa' merkinneelle vaikku-sanalle sen suomen pohjoisimmista murteista tunnetun merkityksen 'voima, tarmo'. Mutta äänteellistäkään vaikutusta ei silloin voi selittää suffiksinvaihdon kautta, kun vaikutuslähteellä ja vaikutuskohteella ei ole mitään yhteistä vartalonkaltaista ainesta uudelleenhahmotettavaksi, vaan yhteys on samantapainen kuin ikonisella sanastolla: näin esimerkiksi skandinaavisperäinen laikku on varmaankin vaikuttanut sanan laukki 'otsatäplä' muotoutumiseen balttilaisperäisen lauka-sanueen jäsenenä. Tällaiset monimuotoiset vaikutussuhteet erilähtöisten sanueitten välillä ovat jääneet liian vähälle huomiolle tähänastisessa itämerensuomen sanaston tutkimuksessa. Ne niputetaan usein affektiperäisen vaihtelun alle, mutta tässä esiin tulleissa tapauksissa ei vaihtelun synnyttäneen muutoksen välittömänä syynä ole ollut sanan affektiivisuus, vaan muun sanaston äänteellinen tai semanttinen läheisyys.

Tämän tutkimuksen perusteella näyttää ilmeiseltä, ettei kantasuomeen ole omaksuttu balttilaislainoja muodossa, jossa pitkää tavuainesta seuraisi vartalonsisäinen geminaattakonsonantti. Ainoan poikkeuksen saattavat muodostaa ekspressiiviset, ennen kaikkea onomatopoieettiset sanat, mutta niissäkin on geminaatta selitettävissä sekundaariksi.

Todennäköinen syy rajoitukseen on, ettei pitkän tavuaineksen jälkeinen geminaatta ollut kohdekielen eli keskikantasuomen sanavartaloissa mahdollinen. Tällöin myös kaikki vastaavanrakenteiset vanhat germaaniset lainat tulisi osoittaa joko keskikantasuomen jälkeisiksi, siis lähinnä kantaskandinaavisiksi, tai tavurakenteeltaan 
sekundaareiksi. Näitä ovat ennen kaikkea LägLoSin varmoina germaanisina lainoina mainitsemat sm. haltta, helppo, hulkka, kalppa, kulppi, laikka, laikko, laukka, laukku, lautta, miekka, nauttia, niittää, nuotta, paittilas, palkka, palkku, pelkka, pilkka, pilkottaa, raippa, raitis, raitti, riutta, ruoke, ruokkia, ruokko, saatto, telkkä, vaippa, vantus, verkkainen, verkko, viikko ja viitta sekä vi. laut, vi. mõót ja valdas. Näitten lainojen suhteellinen ajoittaminen muoto- ja levikkikriteerein on luultavasti mahdollista jo nykyään käytettävissä olevien tietojen pohjalta. Mikäli osa niistä osoittautuu kantagermaanisiksi, voidaan olettaa, että kantagermaaninen äännetaso säilyi kantasuomen kontaktialueella kauemmin kuin balttilaislainojen lähtökieli. Balttilaisen ja germaanisen lainasanaston keskinäisen kronologian nykyistä tarkempi määrittäminen onnistuu siis toivottavasti jo lähitulevaisuudessa.

\section{Kielten lyhenteet}

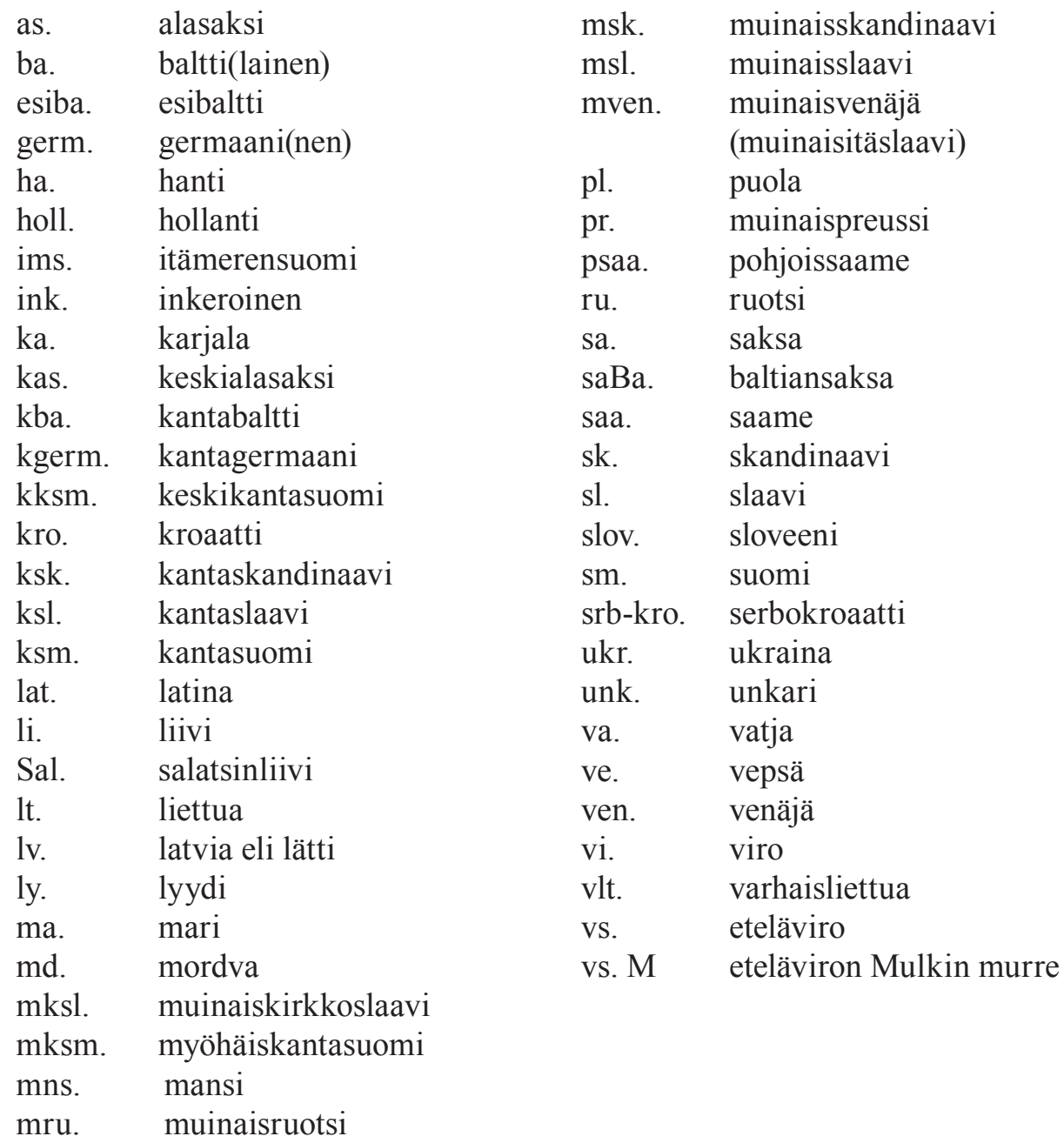




\section{Kirjallisuus}

Aikio, Ante 2009: The Saami loanwords in Finnish and Karelian. Doctoral dissertation.

Aikio, Ante 2012 = Luobbal Sámmol Sámmol Ánte: On Finnic long vowels, Samoyed vowel sequences, and Proto-Uralic *x. - Tiina Hyytiäinen \& Lotta Jalava \& Janne Saarikivi \& Erika Sandman (toim.): Per Urales ad Orientem. Iter polyphonicum multilingue. Festskrift tillägnad Juha Janhunen på hans sextioårsdag den 12 februari 2012. SUST 264: 227-250.

Aikio, Ante 2014: Studies in Uralic etymology II: Finnic etymologies. - Linguistica Uralica L: $1-19$.

Aikio, Ante 2015a = Luobbal Sámmol Sámmol Ánte: Studies in Uralic etymology IV: ObUgric etymologies. - Linguistica Uralica LI: 1-20.

Aikio, Ante 2015b: The Finnic 'secondary e-stems' and Proto-Uralic vocalism. - SUSA 95: $25-66$.

Anderson, Nikolai 1879: Studien zur Vergleichung der ugrofinnischen und indogermanischen Sprachen. Dorpat: Auf Verfügung der gelehrten estnischen Gesellschaft.

Bentlin, Mikko 2008: Niederdeutsch-finnische Sprachkontakte. Der lexikalische Einfluß des Niederdeutschen auf die finnische Sprache während des Mittelalters und der frühen Neuzeit. SUST 256.

BFB = Thomsen, Vilhelm 1890: Beröringer mellem de finske og de baltiske (litauisk-lettiske) sprog: en sproghistorisk undersøgelse. København: Blanco Lunos.

Blokland, Rogier 2005: The Russian loanwords in Literary Estonian. Proefschrift. Groningen.

Breidaks, Antons 1983 = Брейдак, А. Б.: Некоторые данные финно-угорских языков для истории балтийского вокализма. - Baltistica XIX: 46-51.

Būga, Kazimieras 1908: Aistiški studijai. Tyrinejjimai lygintijo prūsu, latvju ir liètuvju kalbômoksljo srityjẹ: I-oji dalis. Peterburgas: Imperatoriškosjos Mokslų Akademijos Spaustuve.

Donner, Otto 1884: Über den Einfluss des Litauischen auf die finnischen Sprachen. - Techmers Internationale Zeitschrift für allgemeine Sprachwissenschaft, I: 257-271.

Däbritz, Chris Lasse 2015: Die Entwicklung des urslavischen und spätgemeinslavischen Vokalsystems: eine phonetische Analyse anhand slavischer Lehnwörter in ostseefinnischen Sprachen. - Finnisch-Ugrische Mitteilungen 39: 1-36.

EDPG $=$ Kroonen, Guus 2013: Etymological dictionary of Proto-Germanic. Leiden IndoEuropean etymological dictionary series 13 . Brill.

EES = Iris Metsmägi \& Meeli Sedrik \& Sven-Erik Soosaar (toim.) 2012: Eesti etümoloogiasõnaraamat. Tallinn: Eesti Keele Sihtasutus.

EEW = Mägiste, Julius 1982-83: Estnisches etymologisches Wörterbuch I-XII. Helsinki: Suomalais-Ugrilainen Seura.

EMS 1994-(2016) = Eesti murrete sõnaraamat 1-(27). Tallinn: Eesti Keele Instituut.

FUF $=$ Finnisch-Ugrische Forschungen. Helsinki: Suomalais-Ugrilainen Seura.

Gimbutas, Marija 1948: Das Dach des litauischen Bauernhauses aus dem 19. Jahrhundert. Stuttgart.

Grunau $=$ Das preussische Vokabular des Simon Grunau — Trautmann, Reinhold: Die altpreußischen Sprachdenkmäler. Göttingen: Vandenhoeck und Ruprecht. 94-96

GSI = Thomsen, Vilhelm 1869: Den gotiske sprogklasses indflydelse på den finske. En sproghistorisk undersøgelse. København: Den Gyldendalske boghandel. 
Hahmo, Sirkka-Liisa 1990: Itämerensuomen *-n: *-ne- vartaloiset nominit. - Congressus Septimus Internationalis Fenno-Ugristarum. Debrecen 27. VIII.-2. IX. 1990. 3 B. Sessiones sectionum. Dissertationes. Linguistica. 209-214.

Hahmo, Sirkka-Liisa 1996: Muutamia etymologiointiperiaatteita. - Congressus Octavus Internationalis Fenno-Ugristarum. Jyväskylä 10.-15. 8. 1995. Pars IV. Sessiones sectionum. Lexicologia \& Onomastica. 53-56.

Hahmo, Sirkka-Liisa 2001: Oliko kantasuomessa denominaalinen johdin $* e h<* e \check{s} ?-$ Congressus Nonus Internationalis Fenno-Ugristarum Tallinnae habitus 7.-13. 8. 2000. Pars IV. Dissertationes sectionum: Linguistica I. 277-283.

Hakulinen, Lauri 1933: Suomen kirki ja kiire - Virittäjä 37: 159-166.

Hakulinen, Lauri 1948: Sanahistoriallista opetusainesta. - Virittäjä 52: 209-210.

Hinderling, Robert 1981: Die deutsch-estnischen Lehnwortbeziehungen im Rahmen einer europäischen Lehnwortgeographie. Wiesbaden: Otto Harrassowitz.

Huldén, Lena 2008: Kuusijalkainen vihollinen. Niveljalkaisten vaikutus länsimaiseen sodankäyntiin. Schildt, Helsinki.

Hyllested, Adam 2014: Word exchange at the gates of Europe. Five millennia of language contact. PhD thesis, University of Copenhagen.

IBL $=$ Kalima, Jalo 1936: Itämerensuomalaisten kielten balttilaiset lainasanat. Suomalaisen Kirjallisuuden Seuran toimituksia XV. Helsinki.

Itkonen, Erkki 1961: Suomalais-ugrilaisen kielen- ja historiantutkimuksen alalta. Tietolipas 20. Helsinki: Suomalaisen Kirjallisuuden Seura.

Junttila, Santeri 2011: Collection of forgotten etymologies. Revisiting the most improbable Baltic loanwords in Finnic. - Cornelius Hasselblatt, Peter Houtzagers, Remco van Pareren (toim.): Language contact in times of globalization. Studies in Slavic and General Linguistics 38: 77-132.

Junttila, Santeri 2012: The prehistoric context of the oldest contacts between Baltic and Finnic languages - Riho Grünthal \& Petri Kallio (toim.): A linguistic map of prehistoric Northern Europe. SUST 266: 261-296.

Junttila, Santeri 2014: Die alten baltischen Lehnwörter im neuen estnischen etymologischen Wörterbuch. - Baltu filologija 23: 126-135.

Junttila, Santeri 2015b: Tiedon kumuloituminen ja trendit lainasanatutkimuksessa. Kantasuomen balttilaislainojen tutkimushistoria. Helsinki: Helsingin yliopisto.

Junttila, Santeri 2016a: Hiljaa hyvä tulee lainasanatutkimuksessakin. - Virittäjä 120: $135-142$.

Junttila, Santeri 2016b: Balttilaislainojen hillitty charmi. - Virittäjä 120: 467-472.

Junttila, Santeri 2016c: Die baltisch-slawische Frage im Lichte der alten baltischen Lehnwörter des Ostseefinnischen. - Baltistica LI: 217-238.

Junttila, Santeri 2017: Lähtökielen sanansisäisten soinnittomien klusiilien edustus kantasuomen balttilaislainoissa. Osa I. Edustus kohdekielen lyhyen vokaalin jäljessä. - SUSA 96: $127-148$.

Junttila, Santeri \& Kaivapalu, Annekatrin \& Metslang, Helle \& Pajusalu, Renate \& Verschik, Anna \& Zabrodskaja, Anastasia 2015: Kümnes Muutuva keele päev. - Keel ja Kirjandus 57: 147-150.

Juvas, Maija \& Vilkuna, Kustaa 1935: Über die kinderreime vom marienkäfer und dessen benennungen im finnischen und estnischen. - FUF 24: 154-231.

LEW = Fraenkel, Ernst 1955-65: Litauisches etymologisches Wörterbuch 1-2. Göttingen.

Kalima, Jalo 1923-24b: Zur karelisch-olonetzischen lautgeschichte. - FUF 16: 163-176. 
Kalima, Jalo 1928: Eräiden sanojen alkuperästä. - Virittäjä 32: 102-111.

Kallio, Petri 2009: Stratigraphy of Indo-European loanwords in Saami. - Tiina Äikäs (toim.): Máttut - máddagat: the roots of Saami ethnicities, societies and spaces. Publications of the Giellagas Institute 12. Oulu. 30-45.

Kallio, Petri 2014: The diversification of Proto-Finnic. - Joonas Ahola \& Frog (toim.): Fibula, fabula fact. The Viking Age in Finland. Studia Fennica Historica 18: 155-168.

Karsten, Torsten Evert 1915: Germanisch-finnische Lehnwortstudien. Ein Beitrag zu der ältesten Sprach- und Kulturgeschichte der Germanen. Acta Societatis scientiarum Fennicae XLV, 2. Helsingfors.

Karsten, Torsten Evert 1937: Beröringar mellan svenskt och finskt folkspråk i Finland med särskild hänsyn till Österbotten - Folkmålsstudier V: 177-220.

Karsten, Torsten Evert 1943-44: Finnar och germaner. Folk- och kulturberöringar från tre årtusenden. - Folkmålsstudier IX, s. I-VIII + 1-260 ja Folkmålsstudier X.

Kettunen, Lauri 1934: Keelelisi tähelepanekuid vepsa retkelt - Eesti Keel XIII: 130-37 ja 169-175.

Kim, Jeongdo 2015: Onomatopoeettisuuttako vain? Uusia lainaetymologioita suomen onomatopoeettisille sanoille. - Sananjalka 57: 129-150.

Kiparsky, Valentin 1936: Fremdes im Baltendeutsch. Mémoires de la société Néo-philologique de Helsingfors XI.

Kivinen, Ilona 2007: Värinnimitysten synty suomalais-ugrilaisissa kielissä, lähtökohtana 'musta'. Pro-gradu -työ, Helsingin yliopisto, Suomalais-ugrilainen laitos.

Klimavičius, Jonas 1977: Aistès - Kalevalos šalies marčios. - Žmoness ir kalba. Vilnius: „Mokslas“. 102-119.

Koivulehto, Jorma 1971a: “Jäten” in deutschen Mundarten. Wortgeographisch-etymologische Untersuchungen. Helsinki: Suomalainen Tiedeakatemia.

Koivulehto, Jorma 1971b: Germanisch-finnische Lehnbeziehungen I. - Neuphilologische Mitteilungen 72: 577-607.

Koivulehto, Jorma 1971c: Vanhimmista germaanis-suomalaisista lainakosketuksista. Sm. karsia $\sim$ germ. skarđian. - Virittäjä 75: 380-388.

Koivulehto, Jorma 1972: Germanisch-finnische Lehnbeziehungen II. - Neuphilologische Mitteilungen 73: 575-628.

Koivulehto, Jorma 1989: Ehkä ja ehto, yskä ja ystävä. - SUSA 82: 171-192.

Koivulehto, Jorma 1997: Die Datierung der germanisch-finnischen Kontakte, revidiert. Sirkka-Liisa Hahmo, Tette Hofstra, László Honti, Paul van Linde \& Osmo Nikkilä (toim.): Finnisch-ugrische Sprachen in Kontakt. Vorträge des Symposiums aus Anlaß des 30-jährigen Bestehens der Finnougristik an der Rijksuniversiteit Groningen 21. 23. November 1996. Maastricht: Shaker. 11-33.

Koivulehto, Jorma 2005: Noin jalot vietettiin hevonsuistajan Hektorin peijaat: peijaiset- ja peikko-sanojen etymologia. - Virittäjä 109: 322-335.

Koivulehto, Jorma 2006: Wie alt sind die Kontakte zwischen Finnisch-Ugrisch und Balto-Slavisch? - Juhani Nuorluoto (toim.): The Slavicization of the Russian North. Mechanisms and Chronology. Slavica Helsingiensia 27. Helsinki. 179-196.

Koivulehto, Jorma 2009: Etymologisesti hämäriä -(is)tA-johdosverbejä, lainoja ja omapohjaisia. - SUSA 92: 79-102.

Koponen, Eino 1998: Eteläviron murteen sanaston alkuperä. Itämerensuomalaista etymologiaa. SUST 230. 
Koski, Mauno 1986: Zur morphologischen Restrukturierung und zu semantisch-morphologischen Interdependenzen im ostseefinnischen Wortschatz. - Советское финно-угроведение XXII: 177-186.

Kulonen, Ulla-Maija 1996: Sanojen alkuperä ja sen selittäminen. Etymologista leksikografiaa. Helsinki: Suomalaisen Kirjallisuuden Seura.

Lehtinen, Tapani 2007: Kielen vuosituhannet. Suomen kielen kehitys kantauralista varhaissuomeen. Tietolipas 215. Helsinki: Suomalaisen Kirjallisuuden Seura.

LEW = Fraenkel, Ernst 1955-65: Litauisches etymologisches Wörterbuch 1-2. Göttingen.

Lidén, Evald 1911: Baltisch-slavische worterklarungen. - Le Monde Oriental V: 197-204.

Linde, Paul van 2007: The Finnic vocabulary against the background of interference. Proefschrift ter verkrijging van het doctoraat in de Letteren aan de Rijksuniversiteit Groningen op gezag van de Rector Magnificus, dr. F. Zwarts, in het openbaar te verdedigen op donderdag 25 oktober 2007 om 14.45 uur.

Lindström, Johan Adolf 1852: Samling av med finskan beslägtade ord från den Uralska, Altaiska och Kaukasiska språken - Suomi XII: 1-110.

Liukkonen, Kari 1999: Baltisches im Finnischen. SUST 235.

LKŽ 1941-2002 = Lietuviu kalbos žodynas I-XX. Vilnius.

Lust, Kersti \& Pae, Taavi \& Saar, Evar 2017: Veel kord mulkide rumalusest. - Keel ja Kirjandus 59: 863-874.

LW = Kettunen, Lauri 1938: Livisches Wörterbuch. Helsinki: Suomalais-Ugrilainen Seura.

LägLoS = Andries Dirk Kylstra, Sirkka-Liisa Hahmo, Tette Hofstra, \& Osmo Nikkilä 19912012: Lexikon der älteren germanischen Lehnwörter in den ostseefinnischen Sprachen 1-3. Amsterdam - Atlanta: Rodopi.

ME = Jānis Endzelīns (toim.) 1923-32: K. Mũ lenbacha Latviešu valodas vārdnīca I-IV. Rīga: Kultūras fonds.

Metsmägi, Iris 2015: Tüve roobas rööbas päritolust. - Emakeele Seltsi aastaraamat 61: $155-166$.

Mikkola, Jooseppi Julius 1894: Berührungen zwischen den westfinnischen und slavischen Sprachen. I. Slavische Lehnwörter in den westfinnischen Sprachen. SUST VIII.

MndW = Schiller Karl \& Lübben August 1875-81: Mittelniederdeutsches Wörterbuch 1-6. Bremen: Kühtmann.

Must, Mari 2000: Vene laensõnad eesti murretes. Tallinn: Eesti Keele Sihtasutus.

Mägiste, Julius 1927: Lmsm. keelte kuradinimestikust. - Eesti Keel VI: 66-84.

Mägiste, Julius 1928: oi-, ei-deminutiivid läänemeresoome keelis. Läänemeresoome nominaaltuletus I. Eesti Vabariigi Tartu Ülikooli Toimetused B XII 2.

Mägiste, Julius 1932: Kõhklevaid mõtteid läänemere-soome laensõnade-uurimise puhul. Eesti Keel XI: 129-142.

Mägiste, Julius 1936: Jalo Kalima, Itämerensuomalaisten kielten balttilaiset lainasanat. Eesti Keel XV: 182-186.

Mägiste, Julius 1956: Zu einigen fraglichen alten ostseefinnischen Lehnwörter aus dem Russischen. - Arsbok för läsåret 1949/50 utgiven av seminarierna i slaviska språk, jämförande språkforskning, finsk-ugriska språk och östasiatiska språk vid Lunds universitet. $19-65$.

Mägiste, Julius 1977: Zu einigen vermeintlichen baltischen Lehnwörtern in den ostseefinnischen Sprachen. - Denis Sinor (toim.): Studies in Finno-Ugric Languages In Honor of Alo Raun. Indiana University Uralic and Altaic Series 131. Bloomington. 155-175. 
Nieminen, Eino 1940: Itämerensuomalaisten ja balttilaisten kielten välisten kosketusten tutkimuksesta. - Virittäjä 44: 376-384.

Nieminen, Eino 1944: Eräistä balttilaisista lainasanoistamme ja niiden vastineista. - Virittäjä 48: $238-250$.

Nieminen, Eino 1953: Ein Beitrag zu der ostslawischen und ostseefinnischen Badeterminologie. - Lingua Posnaniensis IV: 211-228.

Nieminen, Eino 1959: Beiträge zu den baltisch-ostseefinnischen Berührungen. - E. Sokols (toim.): Rakstu krājums. Veltījums akadēmiķim profesoram Dr. Jānim Endzelīnam vina 85 dzīves un 65 darba gadu atcerei. Rīgā: Latvijas PSR Zinātnu Akadēmijas izdevniecība. 201-210.

Nieminen, Eino 1963: Ausdrücke für Bau-, Arbeits- und Nutzhölzer fremden Ursprungs im Finnischen. - Zeitschrift für slavische Philologie XXXI: 233-241.

Nikkilä, Osmo 1982: Wörter für 'Körper' germanischen Ursprungs im Ostseefinnischen. Советское финно-угроведение XVIII: 251-260.

Nikkilä 2001: Fragwürdige Lehnwortforschung. - FUF 56: 394-403.

Ojansuu, Heikki 1916: Suomen kielen tutkimuksen työmaalta. Sarja esitelmiä I.

Ojansuu, Heikki 1921: Lisiä suomalais-balttilaisiin kosketuksiin. Vähäisiä kirjelmiä XLIX. Helsinki: Suomalaisen Kirjallisuuden Seura.

Orrman, Jaakko 1993: Mahdollisia balttilaisia etymologioita: haitta, huttu, rovio. - Virittäjä 97: 99-101.

Ostrowski, Norbert 2014: On the postponed neuter pronoun *-ja in Baltic. - Tatjana Civjan, Marija Zavjalova \& Artūras Judžentis (toim.): Baltai ir slavai: dvasiniu kultūru sankirtos. Vilnius: Versmè. 242-253.

Pais, Dezső 1962: Szer. Verzweigungen einer Wortfamilie im Ungarischen und in den anderen finnischugrischen Sprachen. - Acta Linguistica Academiae Scientiarum Hungariae XII: $1-18$.

Penttilä, Aarni 1938: Suuri liivin sanakirja. - Virittäjä 42: 491-497.

Peterson, Aleksei $1980=$ Петерсон, А. Ю: Латышское pirts и вепсское pert' в аспекте древнейших этнических связей. - Marta Rudzīte, Saulvedis Cimermanis \& Mirdza Slava (toim.): Этнографические и лингвистические аспекты этнической истории балтских народов. Рига: „Зинатне“. 106-111.

POS 1967-(2016) = Псковский областной словарь с историческими данными 1-(26). Издательство Санкт-Петербургского университета.

Posti, Lauri 1977: Some new contributions to the stock of Baltic loanwords in Finnic languages. - Baltistica XIII: 263-270.

Rauhala, Ilona 2014: Adaptation of loanwords of the suffix type *-eTA in Finnish and Saami. - FUF 62: 283-326.

Rédei, Károly 2000: Kari Liukkonen, Baltisches im Finnischen, Helsinki 1999. - Linguistica Uralica XXXVI: 226-229.

REW = Vasmer, Max 1953-58: Russisches etymologisches Wörterbuch 1-3. Heidelberg.

RGA = Herbert Jankuhn \& Heinrich Beck (toim.) 1973-2008: Reallexikon der Germanischen Altertumskunde 1-37. Berlin: De Gruyter.

Ritter, Ralf-Peter 1977: Zur Frage der finnischen Evidenz für die Sievers'sche Regel im Germanischen. - Die Sprache 23: 171-179.

Rytkönen, Ahti 1937: Vaikku. - Kalevalaseuran vuosikirja 17: 73-82.

Saareste, Albert 1922: Etümoloogilised märkused I-II. - Eesti Keel I: 15-24 ja 140-150.

SAOB 1893-(2017) = Svenska Akademiens ordbok 1-(37). Lund. 
Saxén, Ralf 1895-98: Finska lånord i östsvenska dialekter. Språkhistoriska studier. Bidrag till kännedom om de svenska landsmålen och svenskt folkliv XI. 3. Stockholm.

Schalin, Johan 2018: Preliterary Scandinavian sound change viewed from the east. Umlaut remodelled and language contact revisited. Nordica Helsingiensia 54. Helsinki: Helsingin yliopisto.

SEJL = Smoczyński, Wojciech 2007: Słownik etymologiczny języka litewskiego. Wilno: Uniwersytet Wileński, Wydział Filologiczny.

SEO = Hellquist, Elof 1939: Svensk etymologisk ordbok. Ny, omarbetad och utvidgad upplaga. Lund: Gleerup.

Setälä, Emil Nestor 1891: Yhteissuomalainen äännehistoria. Suomalaisen Kirjallisuuden Seura, Helsinki.

Setälä, Emil Nestor 1915: Reunamuistutuksia. - Virittäjä 19: 78-82.

SKES 1955-79 = Suomen kielen etymologinen sanakirja I-VII. Suomalais-Ugrilainen Seura, Helsinki.

SMS 1985-(2008) = Suomen murteiden sanakirja 1-(8). Helsinki: Kotimaisten kielten tutkimuskeskus.

SSA 1992-2000 = Suomen sanojen alkuperä. Etymologinen sanakirja 1-3. Helsinki: Kotimaisten kielten tutkimuskeskus - Suomalaisen Kirjallisuuden Seura.

SUSA = Suomalais-Ugrilaisen Seuran Aikakauskirja. Helsinki: Suomalais-Ugrilainen Seura. SUST $=$ Suomalais-Ugrilaisen Seuran Toimituksia. Helsinki: Suomalais-Ugrilainen Seura.

Suhonen, Seppo 1973: Die jungen lettischen Lehnwörter im Livischen. SUST 154.

Suhonen, Seppo 1992: An der Grenze zwischen Entlehnung und Onomatopoesie. - Deréky Pál, Marianne Sz. Bakró-Nagy, Timothy Riese \& Péter Hajdú (toim.): Festschrift für Károly Rédei zum 60. Geburtstag. Wien - Budapest. 415-419.

Suhonen, Seppo 1998: Lättiläis-virolaisia kielisuhteita. - Virittäjä 102: 630-604.

Suomen murteiden sana-arkisto. Kotimaisten kielten keskus.

SVJa = Зайцева, М.И. \& Муллонен, М.И.: Словарь вепсского языка. Ленинград: Издательстио «Наука».

Tesz 1967-84: = A magyar nyelv történeti-etimológiai szótára I - III. Budapest: Akadémiai Kiadó.

Toivonen, Yrjö Henrik 1919: Etymologisia huomioita. - Virittäjä 23: 101-111.

Toivonen, Yrjö Henrik 1931: Vaikku, vaikuttaa. - Sanakirjasäätiön toimituksia I: 31-36.

Uotila, Eeva 1970: Finn. *laukas $e^{*}$ valka- / *älkä-. Euroasiatica 1970: 7. Napoli: Istituto Universario Orientale.

Uotila, Eeva 1992: New loans from Germanic and Baltic - Finnish kersa, nuutua, synkkä. - Finnisch-ugrische Sprachen zwischen dem germanischen und dem slavischen Sprachraum. Vorträge des Symposiums aus Anlaß des 25-jährigen Bestehens der Finnougristik an der Rijksuniversiteit Groningen 13.-15. November 1991. Amsterdam: Rodopi. 167-173.

Vaba, Lembit 1987: Mauno Koski, Värien nimitykset suomessa ja lähisukukielissä. Советское финно-угроведение XXIII: 219-226.

Vaba, Lembit 1989: Balti laenud läänemeresoome maastikusõnavaras. - Keel ja Kirjandus 32: 138-141, 206-218.

Vaba, Lembit 1990: Die baltischen Sonderentlehnungen in den ostseefinnischen Sprachen. - Itämerensuomalaiset kielikontaktit. Itämerensuomalainen symposium 7. kansainvälisessä fenno-ugristikongressissa Debrecenissä 27.8. - 1.9.1990. Helsinki: Valtion Painatuskeskus. 125-139. 
Vaba, Lembit 1992: Käblik on ahjulind! - Keel ja Kirjandus 35: 459-462.

Vaba, Lembit 1996: Ühest balti päritolu lõunaeestilise levikuga sõnarühmast. - Congressus Octavus Internationalis Fenno-Ugristarum. Jyväskylä 10.-15. 8. 1995. Pars IV. Sessiones sectionum. Lexicologia \& Onomastica. 205-209.

Vaba, Lembit 1997: Uurimusi läti-eesti keelesuhetest. Tallinn - Tampere.

Vaba, Lembit 2004: Ein eventuelles baltisches Lehnverb in der Südgruppe der ostseefinnischen Sprachen. - Peter Anreiter, Marialuise Haslinger \& Heinz Dieter Pohl (toim.): Artes et scientice. Festschrift für Ralf-Peter Ritter zum 65. Geburtstag. Wien: Edition Praesens. 547-553.

Vaba, Lembit 2014: Alternatiivseid etümoloogiaid. - Emakeele Seltsi aastaraamat 60: 219-231.

Vaba, Lembit 2015: Über monophthongische Substitute baltischer resp. lettischer Diphthonge in südestnischen Lehnwörtern - Linguistica Uralica LI: 21-27.

Vaba, Lembit 2017: Rumalad mulgid ehk etümologiseerimise okkaline tee. - Keel ja Kirjandus 59: 534-540.

Vahros, Igor 1966: Zur Geschichte und Folklore der grossrussischen Sauna. FF Communications 197. Helsinki: Suomalainen Tiedeakatemia.

Valonen, Niilo \& Vuoristo, Osmo 1994: Suomen kansanrakennukset Seurasaaren ulkomuseon rakennusten pohjalta. Helsinki: Museovirasto.

WDSL = von Gutzeit, W. 1859-98: Wörterschatz der deutschen Sprache Livlands I-IV + Nachträge. Riga: Kymmel.

VES = Sullõv Jüvä (toim.) 2002: Võro-eesti synaraamat. Tarto - Võro: Võro Instituut'.

Wiklund, Karl Bernhard 1911: Zur kenntnis der ältesten germanischen lehnwörter im finnischen und lappischen. - Le Monde Oriental V: 217-252.

Vilkuna, Asko 1965: Kalannimistä kulttuurintutkimuksen lähteenä. Suomi 111: 2. Helsinki: Suomalaisen kirjallisuuden Seura.

VMS = Valdek Pall (toim.) 1982-89: Väike murdesõnastik I-II. Tallinn: Eesti Teaduste Akadeemia Keele ja Kirjanduse Instituut.

VRS = Helamaa, Erkki 2004: Vanhan rakentajan sanakirja: rakentamisesta, rakennuksista, rakenteista. Helsinki: Suomalaisen Kirjallisuuden Seura.

Zeps, Valdis 1962: Latvian and Finnic linguistic convergences. Uralic and Altaic series 9. Bloomington: Indiana University Press. 